\title{
ARTICLES
}

\section{THE USE OF CROSS-BORDER CORPORATE PROFITS AND LOSSES AND "GLOBAL CORPORATE TAX INFORMATION": A GAME THEORY APPROACH}

\author{
Carlo Garbarino*
}

\begin{abstract}
The paper, proposes a game theory approach based on a concept of Global Corporate Tax Information and analyzes the unilateral strategies a country can select from to regulate cross-border profits and losses in its capacity as a residence-country or as a source-country. A description of the strategies available to residence-countries when there is no exchange of Global Corporate Tax Information is developed in section 2. Section 3 then looks at the interactions of those unilateral strategies of residence and source countries when there is no exchange of Global Corporate Tax Information, and shows that they lead to a stable uncooperative equilibrium as the result of "dominant strategies." Section 4 emphasizes the strategic importance of Global Corporate Tax Information insofar as it is conducive to effective cooperation in enforcement that prevents aggressive strategies by global taxpayers and shows that such coordination can be backed by multilateral commitment. Section 4 also demonstrates that the Common Consolidated Corporate Tax Base ("CCCTB") can be viewed as a multilateral method for the exchange of Global Corporate Tax Information if approved by at least nine EU countries (i.e. the minimum number of parties required under the "enhanced cooperation" procedure.) Section 5 concludes by proposing that the U.S. could become a party to pre-existing multilateral systems for exchange of Global Corporate Tax Information such as the CCCTB.
\end{abstract}

${ }^{*}$ Professor of Law, Bocconi University, Milan; Hauser Global Visiting Faculty, NYU Law School, 2013; Visiting Professor of Law, University of Michigan Law School, 2008, 2011, 2012; Visiting Professor of Law, University of Florida School of Law, 2011; Visiting Professor, University of San Paulo, 2010; Visiting Scholar, University of Michigan Law School, 2009; Visiting Professor, Sorbonne University, Paris, 2005, 2007; Visiting Scholar, Yale Law School, 1987-1988. The author gratefully acknowledges comments from Reuven Avi-Yonah, Joshua Blank, Yariv Brauner, Daniel Shaviro, Mitchell Kane, and Alan Sykes. 
I. CONSOLIDATION OF CROSS-BORDER PROFITS AND LOSSES: A GAME THEORY APPROACH TO EXCHANGE OF GLOBAL CORPORATE TAX INFORMATION

II. UNILATERAL TAX STRATEGIES OF RESIDENCE AND SOURCECOUNTRIES IN RESPECT TO CROSS-BORDER PROFITS AND LOSSES ...... 145

III. THE INTERACTIONS OF UNILATERAL COUNTRIES' POLICIES: DOMINANT STRATEGIES AND UNCOOPERATIVE BEHAVIOR 150

IV. THE COORDINATION OF RESIDENCE AND SOURCE COUNTRIES BASED ON THE EXCHANGE OF GLOBAL CORPORATE TAX INFORMATION: THE CCCTB MODEL 155

V. THE EXTENSION OF THE CCCTB AS A MULTILATERAL TREATY ON EXCHANGE OF GLOBAL CORPORATE TAX INFORMATION 


\section{CONSOLIDATION OF CROSS-BORDER PROFITS AND LOSSES: A GAME THEORY APPROACH TO EXCHANGE OF GLOBAL CORPORATE TAX INFORMATION}

Profits and losses should, in theory, fall under the tax jurisdiction of the country where they have been generated. Shifting profits and losses across borders through purposeful planning shields profits earned in high-tax jurisdictions from their natural tax rates and allows losses to be transferred and used to reduce the effective rate on profits located elsewhere. This is one of the techniques that lead to the creation of what has been denominated "stateless income." ${ }^{1}$ An emerging international policy issue, the shifting of profits and losses prevents the attainment of essential benchmarks of tax neutrality, according to which income should be taxed in the jurisdiction where it is generated. ${ }^{2}$ The OECD, in a 2011 report entitled "Corporate Loss Utilization through Aggressive Tax Planning," noted that due to the recent financial and economic crisis, global corporate losses have become enormous. ${ }^{3}$ In a subsequent 2013 report, it provided a definition of "base erosion and profit shifting" (BEPS), ${ }^{4}$ an even wider phenomenon which has attracted the attention of governments ${ }^{5}$ and the EU. ${ }^{6}$ This recently escalated in major

1 "Stateless income" has been defined as income that is "derived for tax purposes by a multinational group from business activities in a country other than the domicile of the group's ultimate parent company, but which is subject to tax only in a jurisdiction that is not the location of the customers or the factors of production through which the income was derived, and is not the domicile of the group's parent company." Edward D. Kleinbard, Stateless Income, 11 Fla. TAX REV. 699, 701 (2011).

${ }^{2}$ See, e.g., Fadi Shaheen, International Tax Neutrality: Reconsiderations, 27 VA. TAX Rev. 203, 211, 213-14 (2007) (surveying and evaluating various theories of tax neutrality and proposing best satisfying capital export neutrality); Joel Slemrod, Location, (Real) Location, (Tax) Location: An Essay on Mobility's Place in Optimal Taxation, 63 NAT'L TAX J. 843, 844 (2010) (examining the nature and proper role of mobility in optimal taxation); George R. Zodrow, Capital Mobility and Capital Tax Competition, 63 NAT'L TAX J. 865, 881 (2010) (exploring the extent of tax competition for mobile capital).

${ }^{3}$ Organization for Economic Co-operation and Development ("OECD"), Corporate Loss Utilisation through Aggressive Tax Planning (Paris, 2011) (exploring the strategic use of corporate losses, how such strategies can frustrate the purposes of legislators, and giving recommendations for tax administrators and tax policy officials). See also D.R. Post \& Kelly Stals, The Tax Treatment of Corporate Losses: A Comparative Study, 40 INTERTAX 232 (2012) (detailing a 50 country survey concerning the tax treatment of corporate losses and responding to the OECD report regarding the use of aggressive tax planning to use corporate losses).

${ }^{4}$ For the definition of "base erosion and profit shifting," see OECD, Addressing Base Erosion and Profit Shifting, Paris, 2013. See also Kimberly A. Clausing, The Revenue Effects of Multinational Firm Income Shifting, TAX NOTES 1580-1586 (2011); Dhammika Dharmapala \& Nadine Riedel, Earnings Shocks and Tax-Motivated Income-Shifting: Evidence from European Multinationals, 97 J. PuB. Econ. 95-107 (2013); Clement Fuest \& Nadine Riedel, Tax Evasion and Tax Avoidance in Developing Countries: the Role of International Profit Shifting (Oxford University Centre for Business Taxation, Working Paper 10/12, June 2010), available at http://eureka.bodleian.ox.ac.uk/3257/1/WP1012.pdf.

${ }^{5}$ See, e.g., The Rt Hon George Osborne MP, Chancellor of the Exchequer, HM Treasury, Britain and Germany call for international action to strengthen tax standards (Nov. 5, 2012), available at https://www.gov.uk/government/speeches/statement-by-the-chancellor-of-the-exchequer-rt-hon-georgeosborne-mp-britain-germany-call-for-international-action-to-strengthen-tax-standards. In that Statement German Finance Minister Wolfgang Schäuble and British Chancellor of the Exchequer George Osborne have called on the G20 countries to coordinate efforts to prevent profit shifting by companies of all nationalities and to protect the global corporate tax base. Id. The same issues were discussed at the 2012 G20 Los Cabos summit. Group of Twenty ("G20"), Los Cabos Summit Leader's Declaration, (Jun. 19, 2012), https://www.g20.org/sites/default/files/g20_resources/library/G20_Leaders_Declaration_Final_Los_Cabos.p df; G20, G20 Finance Ministers and Central Bank Governors Mexico February 2012 Communiqué (Feb. 2526, 2012),

https://www.g20.org/sites/default/files/g20_resources/library/250212_Finance_Ministers_and_Central_Bank _Governors.doc. 
corporate tax cases involving multinationals. In the US, similar cases were brought to the attention of the public ${ }^{7}$ and have been scrutinized by the U.S. Senate Permanent Subcommittee on Investigation. ${ }^{8}$ Similar issues have been discussed in the UK and other countries. $^{9}$

These losses raise tax compliance risks, in particular if global multinational firms operating through affiliate companies (hereinafter "Global Taxpayers") turn to aggressive cross-border tax planning as a means of increasing and/or accelerating tax relief. The overall effect of this type of tax planning is to erode the corporate tax base of many countries because BEPS pursued through the utilization of cross-border profits and losses often takes advantage of a combination of features of tax systems of home and host countries. This implies that it may be very difficult for any single country, acting alone, to effectively combat these BEPS behaviors. ${ }^{10}$ The crux of the problem therefore is twofold: on the one hand, national tax authorities do not have access to information concerning the profits and losses of non-resident companies, and, on the other hand, global taxpayers, such as multinational firms, are capable of exploiting this information gap by carrying out aggressive tax planning that reduces their overall effective rates.

National tax authorities have access to information on domestic corporate profits or losses, but can obtain information on foreign corporate profits or losses only if there is a tax information exchange agreement with the relevant foreign country. By contrast, global taxpayers do not face territorial information limits and have access to relevant tax data on a global scale. This asymmetry of information enhances arbitrage opportunities for global taxpayers. As noted by the OECD, "while these corporate tax planning strategies may be technically legal and rely on carefully planned interactions of a variety of tax rules and principles, the overall effect of this type of tax planning is to erode the corporate tax base of many countries in a manner that is not intended by domestic policy. This reflects the fact that BEPS takes advantage of a combination of features of tax

\footnotetext{
${ }^{6}$ Press Release, General Secretariat of the Council, European Council 22 May 2013 Conclusions, EUCO 75/1/13 REV 1 (May 23, 2013).

${ }^{7}$ See, e.g.,David Kocieniewski, Series, But Nobody Pays That, N.Y. TimEs, Mar. 25-Dec. 30, 2011, available at topics.nytimes.com/top/features/timestopics/series/but_nobody_pays_that/index.html; Charles Duhigg \& David Kocieniewski, How Apple Sidesteps Billions in Taxes, N.Y. TIMES, Apr. 28,2012, at A1; Jesse Drucker, Google 2.4\% Rate Shows How \$60 Billion Lost to Tax Loopholes, BlOOMBERG, Oct. 21, 2010, available at http://bloom.bg/gfQvEM; Jesse Drucker, IRS Auditing How Google Shifted Profits Offshore to Avoid Taxes, Bloomberg, Oct. 13, 2011, http://bloom.bg/pa3M73; ROBERT S. MCINTYRE ET AL., Citizens for TAX Justice With the Institute on TAXATION AND ECONOMic Policy, CoRporate TAXPAYERS AND CORPORATE TAX DODGERS 2008-10 (2011), available at www.ctj.org/corporatetaxdodgers/CorporateTaxDodgersReport.pdf; KEVIN A. HASSETT \& APARNA MATHUR, American Enterprise Institute for Public Policy Research , Report Card on EFFeCtive Corporate Tax Rates: United States Gets an F, TAx Policy Outlook No. 1, (2011), available at www.aei.org/files/2011/02/09/TPO-2011-01-g.pdf.; Series, The Great Corporate Tax Dodge, BLOOMBERG, (May 13, 2010-Oct. 27 2013), available at http://topics.bloomberg.com/the-great-corporate-tax-dodge.

${ }^{8}$ Offshore Profit Shifting and the U.S. Tax Code - Part 1 (Microsoft and Hewlett-Packard): Hearing Before the Permanent Subcomm. on Investigation of the S. Comm. on Homeland Sec. and Governmental Affairs, 112th Cong. 781 (2012); Offshore Profit Shifting and the U.S. Tax Code - Part 2 (Apple): Hearing Before the Permanent Subcomm. on Investigation of the S. Comm. on Homeland Sec. and Governmental Affairs, 113th Cong. 90 (2013).

${ }^{9}$ Public Accounts Committee, HM Revenues and Customs: Annual Report And Accounts 2011- 12, TAX AVOIDANCE By MULtinational COMPANIES, 2012-3, H.C. 716 (U.K.). See also, Jim Pickard \& Vanessa Houlder, Google and Starbucks face tax questions, FIN. TIMES, Oct. 30, 2012, available at http://on.ft.com/Q4w7wu; Juliette Garside, Amazon Paid £3m tax on £4bn UK Sales, THE GuARDIAN, May 15, 2013, available at $\mathrm{http}: / / \mathrm{gu} . \mathrm{com} / \mathrm{p} / 3 \mathrm{fpgb} / \mathrm{tw}$.

${ }^{10}$ OECD, Addressing Base Erosion and Profit Shifting, supra, note 5, at 7-8.
} 
systems which have been put in place by home and host countries. This implies that it may be very difficult for any single country, acting alone, to effectively combat BEPS behaviors." 11

Governments, therefore, assign strategic value to tax information that concerns cross-border corporate profits and losses; information is generally available by request under Article 26 of the OECD Model Convention, ${ }^{12}$ but the type of tax information that is considered here is that which can be obtained from systems that allow the consolidation by a single company of corporate profits and losses reported by affiliated companies resident in different countries. Such a consolidating company must be in a position to pool together the relevant financial and tax data on profits and losses reported by the consolidated companies and compute consolidated profit and losses on the basis of common rules. This data is available to tax authorities of multiple countries. Such information needed to consolidate cross-border corporate profits and losses is referred to here as "Global Corporate Tax Information."

There is clearly the need for coordinated solutions to be adopted on a multilateral basis relying on the free exchange of Global Corporate Tax Information, but there is no established method for sharing such information. Currently, individual countries do not have access to such information and resort to policies to regulate global taxpayers' use of profits and losses that interact with those of other countries. This article relies on elementary concepts of game theory to provide a simplified model of the strategic behavior of those agents (countries), as each national (i.e. unilateral) tax policy interacts with the others in an environment in which Global Corporate Tax Information becomes a strategic asset for effective tax enforcement. ${ }^{13}$ More precisely each country must choose from a range of unilateral strategies concerning cross-border consolidation of profits and losses. In the stylized model proposed here, a "unilateral strategy" is a predetermined "program of play" that commands what kind of regulation to take in response to every strategy available to other countries. This situation can be technically defined as a "game," i.e. a term of art used to denote a situation in which at least one agent can act to maximize its utility only by anticipating the responses to its actions by one or more other agents by resorting to a unilateral strategy. Game theory is an important tool for an agent, such as a country, ${ }^{14}$ who confronts situations where the best unilateral strategy depends on expectations about what one or more other agents will do, and the other agents' best unilateral strategies depend on what the original agent does.

The model considers two stages of play. In the first stage, countries do not exchange Global Corporate Tax Information and therefore resort to unilateral strategies to regulate cross-border consolidation of profits and losses that maximize their interests. In the second stage, countries exchange Global Corporate Tax Information and eventually abide by common rules embodied in binding legal instruments that reflect and enhance an existing level of spontaneous coordination achieved in the first stage.

${ }^{11}$ OECD, Addressing Base Erosion and Profit Shifting, supra, note 5, at 45.

${ }^{12}$ OECD Model TAX CONVENTION ON INCOME AND CAPITAL 2010.

${ }^{13}$ Game theory has become a massive tool for rational decision-making in all sort of field and it is not the case here to review the basic literature. Very useful and comprehensive accounts for the layman are: Binmore Kenneth, Rational Decisions (2009), and Avinash Dixit \& Barry NalebufF, Thinking StRATEGiCAlly (1991). For applications of game theory to law, see Douglas BAIRD, Robert Gertner \& RANDAL PiCKER, GAME THEORY AND THE LAW (1994).

14 The concept that complex institutions such as governments or countries can meaningfully be modeled as autonomous agents was introduced by Schelling in his seminal work THOMAS SCHELLING, STRATEGY OF CONFLiCT (1960). 
The intuition behind this account is twofold. First, if certain conditions are met, interactions between unilateral strategies of different countries in the EU might result in a stable equilibrium in which there is a coordinated exchange of Global Corporate Tax Information instrumental to the cross-border tax consolidation of profits and losses of affiliated companies. This would occur for example in the Common Consolidated Corporate Tax Base ("CCCTB") approach, ${ }^{15}$ under which each company's (or branch's) individual tax results are computed and consolidated in accordance with common EU rules. ${ }^{16}$ Second, the US could move towards such a coordinated approach by becoming a party to a multilateral agreement on the exchange of Global Corporate Tax Information, while at the same time pursuing its own unilateral tax policies concerning cross-border profits and losses either in the direction of a territorial system or in the direction of mandatory worldwide consolidation.

For obvious reasons, it would be impossible to map the interactions of these strategies of all countries, so this study examines a sample of countries, specifically the fifteen Member States of the EU before the accession of the new Member States in 2005. From that sample, the study extrapolates wider conclusions, relying on a straightforward application of concepts of game theory, and also considers the policy options which could be taken by the US in respect to cross-border corporate profits and losses and BEPS.

The paper has the following structure. After a concise discussion of the game theory approach that will be exposed in this first section, the paper will go on to analyze the unilateral strategies a country can select from to regulate cross-border profits and losses in its capacity as a residence-country or as a source-country. ${ }^{17}$ A description of the strategies available to residence-countries when there is no exchange of Global Corporate Tax Information is developed in section 2. Section 3 then looks at the interactions of those unilateral strategies of residence and source countries when there is no exchange of Global Corporate Tax Information, and shows that they lead to a stable uncooperative equilibrium as the result of "dominant strategies." Section 4 emphasizes the strategic importance of Global Corporate Tax Information insofar as it is conducive to effective cooperation in enforcement that prevents aggressive strategies by global taxpayers and

${ }^{15}$ Proposal for a Council Directive on a Common Consolidated Corporate Tax Base (CCCTB), SEC (2011) 315 final (Mar. 16 2011). CCCTB superseded a previous approach proposed by the European Commission called Home State Taxation, under which small and medium enterprise were allowed to compute their companies' taxable profits according to the tax rules of the home state of the parent company or head office in accordance with the rules of the Home State.

${ }^{16}$ According to Article 7 where a company qualifies and opts for the system provided for by the CCCTB Directive it shall cease to be subject to the national corporate tax arrangements in respect of all matters regulated by that Directive unless otherwise stated. In particular, Chapters IV, V and VI of the Directive provide common rules respectively for calculating the tax base, for timing and qualifications, and depreciation of fixed assets. On the determination of common base see Iida Jaatinen, IAS/IFRS: A Starting Point for the CCCTB?, 40 InTERTAX 260-269 (2012); Judith Freedman \& Graeme McDonald, The Tax Base for CCCTB: The Role of Principles, in Michael LANG ET AL., COMMON CONSOlidated Corporate TAX BASE $217-270$ (2008).

${ }^{17}$ This concept of residence and source country in respect to cross-border corporate profits and losses will be defined precisely infra, and is slightly different from the standard concept adopted by international tax law according to which every country has the right to impose both residence-based taxation on the worldwide income of its own residents and source-based taxation on income sourced within its borders by non-resident persons. On source tax jurisdiction see for example: RESTATEMENT (THIRD) OF THE FOREIGN RELATIONS LAW OF THE UNited STATES $\$ \$ 411-12$ (1986); REUVEN S. AVI-YONAH, INTERNATIONAL TAX AS International LaW: An ANALysis of THE InTERnational TAX Regime 2 (2007); Stephen E. Shay, J. Clifton Fleming, Jr. \& Robert J. Peroni, The David R. Tillinghast Lecture: "What's Source Got to Do with It?"- Source Rules and U.S. International Taxation, 56 TAX L. REV. 81, 88-106 (2002). 
shows that such coordination can be backed by multilateral commitment. Section 4 also demonstrates that the CCCTB can be viewed as a multilateral method for the exchange of Global Corporate Tax Information if approved by at least nine EU countries (i.e. the minimum number of parties required under the "enhanced cooperation" procedure. $)^{18}$ Section 5 concludes by proposing that the U.S. could become a party to pre-existing multilateral systems for exchange of Global Corporate Tax Information such as the CCCTB.

The remaining part of this section first explains why cross-border corporate profits and losses are generally not consolidated under the rules of a single country, and then defines more precisely the concept of Global Corporate Tax Information within the game theory model used here.

The EU and the US belong to a common policy cluster in which the offsetting of profits and losses of domestic affiliated companies (so called "domestic tax consolidation") is generally allowed, although under different approaches. Fiscal unity is adopted in the US and in the majority of EU countries considered here, ${ }^{19}$ and provides for a systematic pooling by the consolidating company of the profits and losses of the domestic consolidated companies. The same pooling occurs in the variation of fiscal unity in which accounting consolidation is a requirement for tax consolidation. ${ }^{20}$ In group relief, there is a transfer of losses from loss-companies to profitable affiliated companies that are resident in the same country (the United Kingdom and Ireland), while in group contribution there is a transfer of profits from profitable companies to losscompanies in the group that are resident in the same country (Finland and Sweden).

These variants of domestic tax consolidation share a common policy approach, despite the different techniques that are actually implemented, i.e. they allow the offsetting of profits and losses of different companies of a group that are resident in the same country. The view that is taken here is that domestic consolidation essentially takes the form of cooperative correlative adjustments between affiliated companies that are based on a complete sharing of information by those companies with national tax authorities about the corporate profits and losses that are consolidated. For example, those are consolidated by a single company together with all relevant information (in fiscal unity), or otherwise profits/losses are transferred to affiliated companies that can be monitored at the domestic level (in group relief and group contribution). This sharing of information causes simplifications that essentially result from the application of correlative adjustment mechanisms which allow the pooling together of the tax positions of affiliated companies resident in the same country without concessions to the tax sovereignty of other countries. ${ }^{21}$

\footnotetext{
${ }^{18}$ For details about the enhanced cooperation procedure see infra note 41.

${ }^{19}$ Fiscal unity is adopted in the U.S. under the requirement that domestic affiliates be owned by the consolidating company at $80 \%$ of the voting power and value of the stock of a domestic. IRC $\S 1504$ (a) (2012); Treas. Reg. § 1.861-11T(d)(6) (2012). Similar rules are found for example in France, Italy, Spain, Portugal, Austria, Germany, the Netherlands, Luxembourg, Denmark. fiscal unity.

${ }^{20}$ The only country that adopts this approach is Germany, as Austria has abandoned it in favor of

${ }^{21}$ There are other tax design goals that are achieved, at domestic level, by the model of domestic taxation that are ancillary to the offsetting of profits and losses, such as no or limited taxation of capital gains and losses on shares/assets transferred intra-group between resident companies, the exemption of intra-group domestic dividends, the elimination of withholding taxes on flows of income paid between resident companies belonging to the group, as well as the removal of limitations to the deduction of financing expenses incurred in relation to tax exempt participation if certain conditions are met.
} 
These kinds of correlative adjustments are not, however, generally achieved when the affiliated companies are resident in different countries, because cross-border profits and losses create acute coordination problems due to the lack of exchange of Global Corporate Tax Information. First, the inclusion in the residence-country of the losses of foreign affiliated companies or permanent establishments (hereinafter "PEs") triggers the erosion of the national tax base, something that cannot occur in fully domestic tax consolidation. In the US, erosion is achieved through the so called "earnings stripping" strategies that shift profits from one country to another via intragroup deductions/income inclusions, typically through intercompany interest, fees, rents, or royalties, ${ }^{22}$ but also through outright attribution to the US tax jurisdiction of foreign losses. These techniques show that source rules governing the allocation of the deductibility of interest risk become artificial constructs insofar as they allow base erosion by extracting profits from higher to lower rate jurisdictions. ${ }^{23}$

Second, the losses of a foreign affiliated company or PE may be used in the country where the affiliated company or PE is located (through carry forward, carry back, local tax consolidation or other local techniques), and then also used in the country where the controlling company is located (through fiscal unity or group relief) ${ }^{24}$ In the US, "dual consolidated loss" rules limited the ability of US companies to claim the same loss deduction in two different countries, ${ }^{25}$ but the 2007 revisions to the Treasury regulations clarified that interest paid between a so called "check-the-box" disregarded entity and its parent could not give rise to a prohibited dual consolidated loss, even though that loss was deducted against the income of two consolidated groups ${ }^{26}$; this effectively opened the door to double dipping for those companies that were pursuing such a goal. ${ }^{27}$

The third concern about cross-border consolidation is that losses of foreign affiliated companies or PEs may be artificially created for the purposes of offsetting domestic profits, but may not be directly audited by the tax authorities of the countries

22 See: Harry Huizinga, Luc Laeven \& Gaetan Nicodeme, Capital Structure and International Debt Shifting, 88 J. Fin. ECON. 80 (2008); Mihir A. Desai, C. Fritz Foley \& James R. Hines Jr., A Multinational Perspective on Capital Structure Choice and Internal Capital Markets, 59 J. FIN. 2451 (2004); Tim Edgar, Jonathan Farras \& Amin Mawant, Foreign Direct Investment, Thin Capitalization, and the Interest Expense Deduction: A Policy Analysis, 56 CAN. TAX. J. 803, 810 (2008); Tim Edgar, Policy Forum: Interest Deductibility Restrictions - Expecting Too Much from REOP?, 52 CAN. TAX. J. 1130 (2004); Julie H. Collins \& Douglas A. Shackelford, Global Organizations and Taxes: An Analysis of the Dividend, Interest, Royalty, and Management Fee Payments Between U.S. Multinationals' Foreign Affiliates, 24 J. ACCT. \& ECON. 151 (1998).

${ }^{23}$ See Richard J. Vann, Taxing International Business Income: Hard-Boiled Wonderland and the End of the World, 2 WoRld TAX J. 305-43 (2010). Michael J. Graetz, A Multilateral Solution for the Income Tax Treatment of Interest Expenses, 62 BULL. INT'L TAX. 486, 489 (2008), recommends in effect a global multilateral treaty to apportion interest expense on pure fungibility of assets principles to all members of an affiliated group of companies, without regard to the identity of the particular affiliate that actually borrowed the funds.

${ }^{24}$ The OECD, Corporate Loss Utilisation through Aggressive Tax Planning, supra note 4, at 42-43 has focused on this issue.

${ }^{25}$ The double dip of losses was generally achieved by consolidating in the U.S. a dual resident losscompany, as such company was also contributing its losses within a domestic consolidation in the other country.

${ }^{26}$ According to the check-the-box rules introduced in 1997, a foreign person can elect whether to be treated as a partnership (i.e., a pass-through entity) or a corporation for U.S. federal tax purposes, and there are exceptions only for certain listed forms of organizations in various countries which are always classified as corporations. Treas. Reg. $\S \S 301.7701-1-301.7701-3$ (2011) (as originally adopted in T.D. 8697, 1997-1 C.B. 215). Before 1997 there was entity classification regulations on a case-by-case basis.

${ }^{27}$ Treas. Reg. $§ 1.1503$ (d) (2007). 
where the company that benefits from such offsetting is located. By the same token, profits of foreign affiliated companies or PEs may be artificially created for the purposes of offsetting them with the losses of other companies. ${ }^{28}$

The game theory model used here is aimed at showing that individual countries could effectively address these asymmetries of information. The model relies on the concept of Global Corporate Tax Information which should be distinguished from the broader concept of "tax information" relating to individual taxpayers, particularly in respect to their passive income held in foreign bank accounts. ${ }^{29}$ At the domestic level, tax information is generally available to tax authorities through the use of their enforcement powers, but becomes scarce when it involves taxpayer facts or circumstances that occur outside the territory of the tax authority. Such foreign tax information has become extremely valuable.

In the current international tax regime, the residence-country has the power to tax the income of its tax-residents produced in a different source-country. There is a risk of moral hazard because of the asymmetry of information, as taxpayers may decide to under-report (or not report) in their country of residence (residence-country) their income produced in the source-country. This opportunistic behavior is generally incentivized by the fact that the residence-country cannot enforce its extra-territorial tax claims in the territory of the source-country, meaning the likelihood of apprehension is dramatically lower. Certain source-countries offer low or no taxation to non-residents investing in that country and do not cooperate with residence-countries in respect to the enforcement of the claims. ${ }^{30}$ Under-reporting (or no reporting) and diversion of investment toward low tax countries is further intensified by the high mobility of certain types of income, such as passive or financial income, as well as by the obfuscation of relevant tax information created by certain source-countries through bank secrecy and other forms of confidentiality, methods used by source-countries specifically to attract foreign investment. $^{31}$

If a country is a low-tax jurisdiction it will act in most cases as a source-country and very seldom will have an interest in obtaining tax information from residence-

\footnotetext{
${ }^{28}$ An abusive use of final losses rule has been encountered in a scheme in which a resident company with a loss-making PE in another EU Member State was converted into a partnership. For the latter State's taxation purposes, as a result of the conversion, the PE was considered to be liquidated and subsequently re-established. The effect was that the hidden reserves of the PE were considered to be realized and the resulting income was offset against the loss carry-forward of the PE. Concurrently, the parent company claimed in its tax return a deduction for the remaining loss carry-forward of the PE from its income referring to Case C-414/06, Lidl Belgium GmbH \& Co KG v FA Düsseldorf-Mettmann, 2008 E.C.R. I-03601, according to which the country of the parent company must allow the deduction of the foreign PE losses when they become final. In addition, in the financial year following the conversion, the PE amortized goodwill and set up a reserve, causing a significant loss and thus shifting the loss carry-forward from the terminated to the re-established business. See OECD, Corporate Loss Utilisation, supra note 4, at 55).

${ }^{29}$ Tax information is the knowledge communicated or received concerning taxpayers' particular facts or circumstances which has a strategic value because it allows agents (governments, tax authorities) to make choices that yield higher expected payoffs/utility than they would obtain from choices made in the absence of information.

${ }^{30}$ Mihir A. Desay,C. Fritz Foley \& James R. Hines Jr., Do Tax Havens Divert Economic Activity?, 90 Econ. LetTers, 219 (2006); Mihir A. Desay, C. Fritz Foley \& James R. Hines Jr., The Demand for Tax Haven Operations, 3 J. PuB. Econ., 513-531 (2006); Dhammika Dharmapala \& James R. Hines, Which Countries Become Tax Havens?, J. PuB. Econ. 93(2009), 1058-68; Dhammika Dharmapala, What Problems and Opportunities are Created by Tax Havens?, 24 OXFORD REV. ECON. POL'Y 661-79 (2008).

${ }^{31}$ See U.N. Office for Drug Control \& Crime Prevention, Financial Havens, Banking SECRECY AND MONEY LAUNDERING (1998).
} 
countries, while if a country is a high-tax jurisdiction it will act in most cases as a residence-country and very often will have an interest in obtaining tax information from source-countries, where its own resident taxpayers may have produced income. The game, then, revolves around resident countries trying to get information from sourcecountries, rather than a reciprocal "exchange" of information. In spite of the language of Article 26 of the OECD Model Convention, this is essentially an asymmetric game, without full reciprocity. Of course two countries may symmetrically exchange information concerning income of individual taxpayers and this occurs when each country, over repeated games, can be at times a residence-country and at times a sourcecountry in respect to such income. This is basically the situation covered by Article 26 of the OECD Model Convention which assumes that the two countries have reciprocal interests.

This asymmetric game led to a situation in which the strategic interests of the high-tax residence-countries clashed with the strategic interests of the low-tax sourcecountries, which has been labeled by high-tax residence-countries as a kind of "uncooperative behavior" that not only stifles the extraterritorial enforcement of the tax laws of the residence-countries, but also hinders the achievement of their favored strategies for taxing foreign income. Resident countries have pushed for a characterization of low-tax source-countries as "tax havens"32 and this has been actively pursued by high-tax residence-countries (typically OECD countries). ${ }^{33}$ The OECD has waged a campaign to enhance the exchange of information and to force uncooperative jurisdictions to make available the relevant information, regardless of domestic constraints (banking confidentiality laws, for example). ${ }^{34}$ The US has also taken a unilateral stance in pursuing its strategic interests by enacting sections 1471 to 1474 of the Internal Revenue Code (the Foreign Account Tax Compliance Act or "FATCA") in 2010, which require foreign financial institutions to report information on financial accounts of US persons and foreign entities by 2015. FATCA is a unilateral move to force foreign financial institutions to disclose their US accountholders or pay a steep penalty for nondisclosure. The result is that foreign financial institutions, to comply with FATCA, may be forced to violate the laws of the jurisdiction in which they are located.

In stark contrast with the asymmetric game played by governments concerning tax information - for example a request by the residence-country to the source-country about individual tax accounts - the game played in respect to Global Corporate Tax Information tends to be a symmetric game. This is because, in the current BEPS scenario involving aggressive strategies by corporate taxpayers with operations truly at multicountry level, each country, over repeated games, can be at times a residence-country and at times a source-country in respect to cross-border corporate profits and losses.

32 See, e.g., CAOrline Doggart, TAx Havens And Their Uses (2002); Lorrain Eden \& Robert T. Kudrle, Tax Havens: Renegade States in the International Tax Regime?, 1 LAW \& POL'Y, 100 (2005); Anthony S. Ginsberg, InTERnational Tax Havens (1997); Mykola Orlov, The Concept of Tax Haven: A Legal Analysis, 32 INTERTAX 95-111 (2004).

${ }^{33}$ Of course there were other major non-tax reasons that drove the fight against tax havens. See, e.g., Donat Masciandaro, Global Financial Crime: Terrorism, Money Laundering, and Offshore CENTRES, 181-218 (2004); WolfGang SchÖN, TAX COMPETITION IN EuROPE (2003); JAE-MyOng KoH, SUPPRESSING TERRORIST FINANCING AND MONEY LAUNDERING (2006).

${ }^{34}$ OECD, Tax Co-Operation: Towards a Level Playing Field, (2006); OECD, TAX CoOPERATION: TOWARds a Level Playing Field(2007); OECD, COUNTERING OfFshore TaX Evasion (2009); OECD, TAX Co-OPERATION 2009: TOWARdS A LEVEl Playing Field (2009). 
When a country acts as a residence-country in respect to cross-border corporate profits and losses, it limits the erosion of the national base, carried by resident persons through certain consolidation techniques that pursue the inflows of foreign losses or profits at the level of the parent company located in the residence-country. When a country acts as a source-country in respect to cross-border corporate profits and losses, it limits the erosion of national base carried by non-resident persons through consolidation techniques in which domestic profits or losses of affiliated companies located in a sourcecountry are transferred to parent companies located abroad. A given country can be at times a residence or a source country in respect to the operations of multinational groups and such a country has an incentive to exchange information to better protect its own interests in all cases (i.e. when it acts as a residence-country and when it acts as a sourcecountry). As a result the game is really about the reciprocal exchange of information among countries, unlike the asymmetric game played in respect to general tax information about individual taxpayers.

In conclusion, in respect to cross-border corporate profits and losses, there is (i) a conflict of interests between governments seeking to protect their own tax bases and global taxpayers seeking to minimize their effective tax rates through BEPS and stateless income techniques, and (ii) a common interest among governments to protect themselves from BEPS and stateless income techniques carried out by global taxpayers.

As reciprocity is incentivized in the sharing of Global Corporate Tax Information, it is reasonable to assume that, for each individual country, the value of that information exceeds the value that can be extracted from merely unilateral strategies that do not enhance cooperation. This assumption informs the rest of this article, and suggests that an individual country that has access to Global Corporate Tax Information can counteract BEPS more effectively. In particular the lack of access to Global Corporate Tax Information hinders the capability of tax authorities of a given country to prevent (i) the erosion of the tax bases that results from the import (or export) of foreign generated profits and losses, (ii) the dual use of losses, and (iii) the artificial creation of income. By contrast, the availability of Global Corporate Tax Information on a multilateral basis would enable countries to effectively enforce rules that prevent these aggressive strategies.

Certain additional assumptions are made in respect to the first stage of the stylized game theory model used here. First, it is assumed that initially agents (i.e. countries) do not communicate and therefore cannot purposefully cooperate. Only in the subsequent stage are communication and cooperation factored into account, during repeated interactions. Second, it is assumed that agents act "rationally," in line with a simplified game-theoretic logic. ${ }^{35}$ Third, it is assumed that at every point where a decision is made an agent knows everything that has happened in the game up to that point. Fourth, it is assumed that such a game is a simultaneous-move game in which agents choose their strategies at the same time. In stage two, the first assumption (that agents do not communicate and do not cooperate) is relinquished and therefore binding (bilateral or multilateral) agreements based on communication and cooperation leading to exchange of Global Corporate Tax Information are contemplated.

${ }^{35}$ Although game theory is not an empirical account of the motivations of actual agents, under the utility and rationality constraint it is able to provide a simplified account at least of rational expectations for the likely behavior of agents. 
These assumptions set up a simplified model in which policy makers are fully informed of the strategies about cross-border profits and losses that are simultaneously adopted by other countries. It is obvious that the actual interdependence of national tax strategies in this regulatory context is more complex than what is suggested by this model. In reality there can be imperfect information, biases in the perception of moves made by other countries, and sequential processes in which countries choose their strategies one after the other. Yet the simplified model reflects the fact that countries interact on a continuous basis over time and thus play so called "repeated games," in which they expect to face each other in similar situations on multiple occasions. ${ }^{36}$

These repeated games are played with future games in mind, and this can significantly alter their outcomes and equilibrium strategies. In such a multi-player situation, countries initially develop their own unilateral tax policies, and then consider the reactions of other countries over time. ${ }^{37}$ In this process, cooperation and coordination thus are two progressive phases of a comprehensive process: cooperation can be minimally defined as the working together of at least two agents (i.e. countries) to achieve a common end, while coordination involves the working together of more than two agents (i.e. countries) in order to exchange information. Coordination, thus, may emerge in a world of agents (such as countries) who operate without central authority and interact repeatedly. This is now a common view that stems from the seminal work of Robert Axelrod, in which he has shown that cooperation can get started in a world of unconditional defectors and evolve from small clusters of individual agents who base their cooperation on reciprocity. Cooperation, once established within a cluster of agents, becomes a full-fledged form of coordination and can protect itself from invasion by less cooperative strategies played by other individual agents, maintaining the prevalence of the cooperative strategy. ${ }^{38}$

One would think that coordination must imply "friendship" and "foresight" as essential elements of a purposive behavior. However, game theory proposes that coordination, in certain situations, can be initially achieved simply out of the combinatorial effects of interactions of individual agents pursuing their own goals, such as countries pursuing unilateral tax strategies (of course such cooperation can then be enshrined in binding legal obligations.) Moreover, while coordination appears to be inherently unstable, game theory proposes that it can be established as a stable equilibrium over repeated games that involve information and unilateral benefits for each actor. This kind of equilibrium is usually defined as an evolutionarily stable equilibrium. ${ }^{39}$ This concept captures two basic ideas: that an equilibrium strategy should be stable against small invasions by "mutants" playing some other strategy, and that communication solves coordination problems. According to this approach, some

\footnotetext{
${ }^{36}$ On the concept of repeated games in legal contexts see, BAIRD, supra note 13, at 159-87.

37 The use of game theory in international law has been proposed by Andrew T. Guzman, $A$ Compliance-Based Theory of International Law, 90 CALIF. L. REV. 1823, 1831,1858 (2002), and applied to international tax law by Tsilly Dagan, The Tax Treaties Myth, 32 N.Y.U. J. INT'L L \& PoL. 939 (2000).

${ }^{38}$ RoBert AXELrod, THE EvOlution OF COOPERATION 59-69 (1984).

39 This concept was originally developed in natural sciences. See JOHn MAYNARD SMITH, EVOLUTION AND THE THEORY OF GAMES (1982), and then it spread to social sciences, see, e.g., JOHN Harsanyi \& Reinhard A. Selten, General Theory of Equilibrium SElection in Games (1988); J. W. Weibull, Evolutionary Game Theory, 59 J. ECON. THEORY, 57-84 (1995); JORGEN WEIBUlL, EvolutionARY GAME THEORY (1995).
} 
threshold number of cooperating agents, who all choose a single strategy, can create a stable equilibrium impervious to occasional mutations. ${ }^{40}$

A multi-country coordination strategy regarding cross-border consolidation of profits and losses can be effectively imposed by a binding legal instrument through which Global Corporate Tax Information is shared. This coordination among several countries would typically occur through a multilateral treaty, and within the EU tax compact, through enhanced cooperation (which requires the approval of a minimum number of nine Member States). ${ }^{41}$ A game theory approach shows that the CCCTB multilateral agreement is effectively the codification of the naturally occurring outcome of the interaction of unilateral strategies of countries in respect to the regulation of cross-border corporate profits. Sections $2-5$ therefore will describe those strategies available to residence and source countries, while the final sections 6-9 will discuss how the interactions of those strategies play out.

\section{UNILATERAL TAX STRATEGIES OF RESIDENCE AND SOURCE- COUNTRIES IN RESPECT TO CROSS-BORDER PROFITS AND LOSSES}

Existing domestic tax consolidation approaches (fiscal unity, group relief, and group contribution) limit, from the perspective of residence-countries, the use of crossborder profits and losses because the information needed about them to apply correlative adjustments on a cross-border level is not accessible to the residence-country. This approach is also adopted by the U.S. as well by other countries that exempt the profits of foreign PEs, although there are some exceptions and is defined here as the "nonrecognition pattern," because it limits the recognition of cross-border profits and losses. ${ }^{42}$

These regimes achieve coordination at the domestic level through correlative adjustments based on the sharing of relevant corporate tax information between the consolidated companies and the local tax authorities, but are inadequate to achieve

\footnotetext{
${ }^{40}$ On the evolution of cooperation see Robert Axelrod \& Douglas Dion, The Further Evolution of Cooperation, 242 SCI., 1385-90 (1988); Robert Axelrod \& William D. Hamilton, The Evolution of Cooperation, 211 SCI., 1390-96 (1981); Robert Boyer \& Andre Orlean, How Do Conventions Evolve?, 2 J. Evol. ECon., 165-77 (1992); Jack Hirshleifer \& Juan Carlos Martinez Coll, What Strategies Can Support the Evolutionary Emergence of Cooperation?, 32 J. CONFLICT RES., 367-98 (1988).

${ }^{41}$ Enhanced cooperation was initially introduced by the Treaty of Amsterdam (1999), which created the formal possibility of a certain number of Member States establishing a concerted action between themselves on matters covered by the Treaties, using the institutions and procedures of the European Union. The European Council made those provisions less restrictive when the Union was enlarged to 27 Member States, and thus the Treaty of Nice (2003) facilitates enhanced cooperation. The right of veto which the Member States enjoyed has been eliminated (except in the field of foreign policy), the number of Member States required for launching the procedure has changed from the majority to nine Member States, and the procedure's scope has been extended to the common foreign and security policies. The general provisions applicable to enhanced cooperation have been grouped together in Title VII of the Treaty on European Union. On enhanced cooperation see Csaba Toro, The Latest Example of Enhanced Cooperation in the Constitutional Treaty: the Benefits of Flexibility and Differentiation in European Security and Defence Policy Decisions and Their Implementation, 11 EuR. L. J., 641-656 (2005); Norberto Nuno Gomes de Andrade, Enhanced Cooperation: The Ultimate Challenge of Managing Diversity in Europe: New Perspectives on the European Integration Process, 40 INTERECONOMICS/REV. EUR. ECON. POL'Y 201-16 (2005); Allemand Frédéric, The Impact of the EU Enlargement to Economic and Monetary Union: What Lessons Can Be Learnt From the Differentiated Integration Mechanisms in an Enlarged Europe?, 11 EuR. L. J., 586-617 (2005); V. Costantinesco, Les clauses de coopération renforcée, le protocole sur l'application des principes de subsidiarité et de proportionnalité, 1997 REV. TRIM. DROIT EUR. 755.

42 This approach is found for example in France, Italy, Spain, Portugal, Austria, Germany, the Netherlands, Luxembourg, Finland, Sweden, the United Kingdom, Ireland, and Denmark. Similar rules are also found in the U.S.
} 
coordination at the cross-border level through similar correlative adjustments which require exchange of Global Corporate Tax Information (for details, see infra Table 1). Fiscal unity (the U.S. belongs to this cluster) does not include foreign losses, and similarly in group relief the transfer of losses is not recognized, either in the country of the recipient, or in the country of the transferor. In group contribution, transfers of foreign profits by foreign affiliated companies are not recognized in the country of the recipient and are not deductible in the country of the transferor. In those systems such restrictions create disparities of treatment between, respectively, comparable resident recipients (for transfers from resident or from non-resident recipients), and comparable domestic transferors (for transfers to resident or to non-resident recipients).

These limitations of domestic tax consolidation systems are essentially due to the lack of access to Global Corporate Tax Information, so a few OECD countries (such as France, Italy and Denmark) have adopted an elective mechanism of international tax consolidation (hereinafter "elective ITC"), or, in a more limited form, a consolidation of foreign PEs which relies on unilateral measures for collecting such information. This approach - defined here as the "recognition pattern" - relies on unilateral collection by the residence-country of information on foreign corporate profits and losses that is achieved by imposing on foreign consolidated companies significant reporting duties to the domestic consolidating. In ITC, the offsetting of profits and losses of all companies of the group, even those resident in different countries, occurs upon election in the country of residence of the ultimate consolidating company, pursuant to the rules of that country. The same effect is obtained with respect to branches, but without election, when consolidation of foreign PEs is allowed. Thus both in the elective ITC and in the mandatory consolidation of foreign PEs there is offsetting of profits and losses of foreign companies or branches.

The goal of elective ITC and consolidation of foreign PEs is achieved by relinquishing the tax deferral on profits or losses of foreign consolidated branches/companies and, as a result, consolidated branches/companies resident in different countries are allowed to offset profits and losses if certain requirements are met. Thus, elective ITC and consolidation of foreign PEs are mechanisms in which the profits and losses of consolidated branches/companies are subject to worldwide taxation in the country of residence of the consolidating company, on the basis of extra-territorial tax jurisdiction and unilateral collection of Global Corporate Tax Information. In both systems, the profits and losses of non-resident consolidated branches/companies are first taxed in the countries where they are located and then in the country of residence of the consolidating company. This results in an overlap of tax jurisdictions which is remedied by a foreign tax credit in the residence-country, by the consolidating company. ${ }^{43}$

The unilateral strategies adopted by residence-countries regulating the consolidation of cross-border profits and losses are summarized in Table 1.

${ }^{43}$ In addition to the offsetting of losses and profits of companies of the group resident in different countries, the model of elective ITC has several intra-group features that are ancillary to the global offsetting of profits and losses, such as no or limited taxation of capital gains and losses on shares/assets transferred cross-border between companies resident in different countries, and exemption of cross-border intra-group dividends. The CCCTB model shares these features with elective ITC, but also it includes the apportionment of income by a formula based on labor, assets and sales, that prevents the need of a foreign tax credit mechanism in the country of the consolidating company. 


\begin{tabular}{|l|l|l|}
\hline $\begin{array}{l}\text { RESIDENCE- } \\
\text { COUNTRY }\end{array}$ & $\begin{array}{l}\text { INFLOW OF FOREIGN } \\
\text { LOSSES }\end{array}$ & $\begin{array}{l}\text { INFLOW OF FOREIGN } \\
\text { PROFITS }\end{array}$ \\
\hline NON- & $\begin{array}{l}\text { A } \\
\text { RECOGNITION } \\
\bullet \text { fiscal unity } \\
\text { group relief } \\
\text { group contribution }\end{array}$ & $\begin{array}{l}\text { B } \\
\bullet \text { fiscal unity } \\
\bullet \text { group relief } \\
\bullet \text { group contribution } \\
\bullet \text { exemption of foreign PEs }\end{array}$ \\
\hline RECOGNITION & $\begin{array}{l}\text { C } \\
\text { elective ITC } \\
\bullet \text { consolidation of foreign PEs } \\
\bullet \text { (mandatory worldwide } \\
\text { consolidation) } \\
\bullet \text { (modified group relief) }\end{array}$ & $\begin{array}{l}\text { D consolidation of foreign PE } \\
\bullet \text { (mandatory worldwide } \\
\text { consolidation) } \\
\bullet \text { (modified group } \\
\text { contribution) }\end{array}$ \\
\hline
\end{tabular}

Unilateral strategies of the residence-countries (Table 1)

The unilateral strategy of a residence-country to limit the inflow of foreign losses from foreign companies to affiliated companies resident in that country is achieved by the methods indicated in cell $\mathbf{A}$ of Table 1. That unilateral strategy is pursued: (i) in countries that adopt fiscal unity through explicit non-recognition of the inflow (i.e. consolidation) of losses of foreign affiliated companies (while such an inflow is allowed for domestically consolidated companies), (ii) in countries that adopt group relief through explicit non-recognition of losses transferred by foreign affiliated companies (while such transfers are allowed for domestic affiliated companies), and (iii) in countries that adopt group contribution in all cases, because that system focuses on the transfer of profits, so it does not need an explicit non-recognition rule on the transfer of losses (by domestic or foreign transferors). The same unilateral strategy is achieved in countries that adopt the exemption of foreign PEs, but there might be exceptions.

The unilateral strategy of a residence-country to limit the inflow (i.e. consolidation) of foreign profits from foreign companies to affiliated companies resident in that country is achieved by the methods indicated in cell $\mathbf{B}$ of Table 1. That strategy is pursued: (i) in countries that adopt fiscal unity through explicit non-recognition of the inflow of profits of foreign affiliated companies (while such an inflow is allowed for domestic consolidated companies), (ii) in countries that adopt group contribution through explicit non-recognition of profits transferred by foreign affiliated companies (while such transfers are allowed for domestic affiliated companies), and (iii) in all cases where a country adopts group relief, because that system focuses on the transfer of losses, so it does not need an explicit non-recognition rule on the transfer of profits (by domestic or

${ }^{44}$ Foreign losses from the perspective of the residence-country are generated in the sourcecountries where the affiliated/controlled companies or the PE are located.

${ }^{45}$ Foreign profits from the perspective of the residence-country are generated in the sourcecountries where the affiliated/controlled companies or the PE are located. 
foreign transferors). The same strategy is achieved in countries that adopt the exemption of foreign PEs, although there might be exceptions. In the US, foreign corporate profits are not included on a current basis, but are fully consolidated when repatriated as dividends.

The unilateral strategy of a residence-country to allow the inflow of foreign losses from foreign companies to affiliated companies resident in that country is achieved by the methods indicated in cell $\mathbf{C}$ of table 1. More precisely, that unilateral strategy is pursued: (i) in countries that adopt elective ITC and (ii) in countries that adopt the consolidation of foreign PEs (of course that strategy would be attained by worldwide mandatory tax consolidation and therefore that approach is included in Table 2, but in parentheses.) Notably, the recognition pattern is never pursued in countries that adopt group contribution, because that system focuses on the transfer of profits, and therefore, always bars the transfer of losses (by domestic or foreign transferors.) This recognition of foreign losses, in theory, could be achieved in countries that adopt group relief by extending to foreign affiliated companies the transfer of losses domestic affiliated companies are allowed (modified group relief.) Such extraterritorial extension of tax jurisdiction, however, is problematic because it might conflict with the domestic rules of source-countries which prohibit deduction of losses transferred to foreign persons. The same result is obtained by mandatory worldwide consolidation. There are no actual instances of these two recognition patterns, and therefore they are included in Table 2 within parentheses.

The unilateral strategy of residence-countries to allow the inflow of foreign profits from foreign companies to affiliated companies resident in that country is achieved by the methods indicated in cell $\mathbf{D}$ of Table 1. That unilateral strategy is achieved: (i) in countries that adopt elective ITC and (ii) in countries that adopt the consolidation of foreign PEs (of course that strategy would be attained by worldwide mandatory tax consolidation and therefore that approach is included in Table 2, but in parentheses). Notably, this strategy is not pursued in countries that adopt group relief because that system focuses on the transfer of losses and therefore always bars the transfer of profits (by domestic or foreign transferors). The recognition of foreign profits, in theory, could be achieved in countries that adopt group contribution by extending to foreign affiliated companies the transfer of profits that is allowed for domestic affiliated companies (modified group contribution), but this extra-territorial extension of tax jurisdiction conflicts with the interest of the source-country to tax those profits and disallow their deduction. The same result is obtained by mandatory worldwide consolidation. There are no actual instances of these two recognition patterns, and therefore they are included in Table 2 within parentheses

The tax design choice source-countries face is different from that of residencecountries as they have to decide whether or not to recognize, for tax purposes, the effects of cross-border transfers of domestic losses or profits to an affiliated company located in the residence-country, when such losses or profits are generated by affiliated companies located in the source-country. This issue is usually addressed by straightforward prohibitions of migrations of losses/profits to and from the source country and this creates disparities of treatment between, respectively, comparable resident recipients (for transfers from resident or from non-resident recipients), and comparable domestic transferors (for transfers to resident or to non-resident recipients). Group relief (the United Kingdom and Ireland) adopts unqualified prohibitions on the transfer/receipt of losses to/from foreign affiliated companies. Group contribution (Sweden and Finland) 
adopts a similar prohibition of transfer/receive profits to/from foreign affiliated companies, although some source-countries adopt an explicit mechanism that provides for local consolidation in the source-country of PEs or companies owned by foreign companies. ${ }^{46}$ In conclusion, group relief and group contribution are the typical strategies that source-countries adopt to prevent the erosion of the national tax base.

By contrast, when a country that adopts fiscal unity (or elective ITC) acts as a source-country, no specific rule is available to limit migrations of domestic profits and losses and therefore fiscal unity is not able either to protect the interests of a sourcecountry or to allow the source-country to cooperate with the residence-country should a taxpayer resident in that country use the losses generated in the source-country. This makes possible the double use of the losses of affiliated companies located in sourcecountries adopting fiscal unity; those losses can be used in the source-country under domestic fiscal unity and at the same time may be recognized in the residence-country (for example if losses of a foreign PE are included in domestic consolidation in the residence-country where the parent company is located.) The US also adopts domestic fiscal unity and therefore lacks an effective strategy to prevent the double use of losses generated within the US when it acts as a source-country. A country that adopts fiscal unity can be targeted by taxpayers that exploit the source-based local use of losses by "double-dipping" on those losses through consolidation in the residence-country as well.

The unilateral strategies of source-countries that regulate the consolidation of global profits and losses are summarized in Table 2.

\begin{tabular}{|l|l|l|}
\hline $\begin{array}{l}\text { SOURCE- } \\
\text { COUNTRY }\end{array}$ & $\begin{array}{l}\text { OUTFLOW OF DOMESTIC } \\
\text { LOSSES }^{47}\end{array}$ & $\begin{array}{l}\text { OUTFLOW OF DOMESTIC } \\
\text { PROFITS }^{48}\end{array}$ \\
\hline $\begin{array}{l}\text { NON- } \\
\text { RECOGNITION }\end{array}$ & $\begin{array}{l}\text { A group relief } \\
\bullet \text { group contribution }\end{array}$ & $\begin{array}{l}\text { B } \\
\bullet \text { group relief } \\
\bullet \text { group contribution }\end{array}$ \\
\hline RECOGNITION & $\begin{array}{l}\text { C (modified group relief) } \\
\bullet \text { (modified group contribution) }\end{array}$ & $\begin{array}{l}\text { D (modified group relief) } \\
\text { (modified group } \\
\text { contribution) }\end{array}$ \\
\hline
\end{tabular}

Unilateral strategies of the source-countries (Table 2)

The unilateral strategy of the source-country to limit the outflow of domestic losses in the direction of residence-countries is achieved by the methods indicated in cell A of Table 2: (i) in countries that adopt group relief, by not allowing the transfer of

${ }^{46}$ Nikolaj Bjørnholm \& Anne Becker-Christensen, The New Danish Tax Consolidation Regime, 46 EUR. TAX'N 47 (2000).

${ }^{47}$ Domestic losses from the perspective of the source-country are generated in that country where the affiliated company is located.

${ }^{48}$ Domestic profits from the perspective of the source-country are generated in that country where the affiliated company is located. 
domestic losses to affiliated companies located in residence-countries (while allowing the transfer of domestic losses to affiliated companies located in the same source-country), (ii) in countries that adopt group contribution in all cases, because that system focuses on the transfer of profits so it always bars the transfer of losses by (domestic or foreign) transferors.

The unilateral strategy of the source-country to limit the outflow of domestic profits to foreign affiliated companies is achieved by the methods indicated in cell $\mathbf{B}$ of Table 2: (i) in countries that adopt group contribution, by not allowing the transfer of domestic profits to affiliated companies located in residence-countries (while allowing the transfer of domestic profits to affiliated companies located in the same sourcecountry), (ii) in countries that adopt group relief, because that system focuses on the transfer of losses so it always bars the transfer of profits by (domestic or foreign) transferors. The outflow of domestic losses or profits could be, in theory, recognized by a modified version of group relief and group contribution (see cells $\mathbf{C}$ and $\mathbf{D}$ of Table 2), by allowing the transfer of domestic losses or profits to affiliated companies located in residence-countries, but in the sample of this study there are no actual instances of that policy, except for the top-down impact of ECJ decisions (consequently in Table 2, modified group relief and contribution are in parenthesis).

\section{THE INTERACTIONS OF UNILATERAL COUNTRIES' POLICIES: DOMINANT STRATEGIES AND UNCOOPERATIVE BEHAVIOR}

Sections 2 has described the unilateral strategies of residence and source countries in respect to cross-border consolidation of profits and losses. This section discusses how the unilateral strategies of residence-countries interact with those of source-countries in the form of a stylized game described by a matrix that shows the outcomes in terms of the agent's utility functions for every possible combination of strategies the agents (i.e. countries) might use.

Individual countries generally adopt consolidation regimes that are aimed at offsetting domestic profits and losses, but do not encompass cross-border issues of migrations of profits and losses; moreover there is no sharing of Global Corporate Tax Information to counteract BEPS. No country has so far cut the Gordian knot and adopted a mandatory worldwide consolidation system that includes both foreign corporate profits and losses in a comprehensive way. Instead, residence-countries and source-countries adopt various unilateral strategies, and as a result there is a high number of possible bilateral situations These situations are described by a multiple-entry matrix in which the columns represent all the strategies that can be adopted by the residence-countries (fiscal unity, group relief, group contribution elective ITC, consolidation/exemption of foreign PEs - see supra Table 1), and the rows represent all the strategies that can be adopted by the source-countries (group relief and group contribution - see supra Table 2). A residence-country adopting fiscal unity may interact with a source-country adopting group-relief, a residence-country adopting group contribution may interact with a sourcecountry adopting fiscal unity, and so on.

Among the numerous combinations of tax policies let us consider by way of an example a situation in which both the residence and the source country adopt group relief as a method to offset profits and losses at the domestic level, i.e. they allow the transfer of losses only between domestic affiliated companies. So in this case the two countries initially do not have information on reciprocal corporate profits and losses and have to decide whether losses should be transferred to a non-resident or recognized by a resident 
recipient when the transferor of those losses in not resident. Note that the losses viewed by the source-country as "domestic" are viewed by the residence-country as "foreign." For example, the losses of a company resident in the source-country and controlled by a company resident in the residence-country are "domestic losses" in the source-country (i.e. the losses of an affiliated domestic company) and "foreign losses" in the residencecountry (i.e. the losses of an affiliated foreign company).

This situation is depicted in Table 3 below. The source-country can adopt two unilateral strategies: one strategy is to protect the national tax base (the domestic losses are non-deductible by the transferor resident in the source-country), and the other strategy is not to protect the national tax base (the domestic losses are deductible by the transferor resident in the source-country). The residence-country can also adopt two unilateral strategies: one strategy is to protect the national tax base (the foreign losses go unrecognized by the recipient resident in the residence-country), and the other strategy is not to protect the national tax base (the foreign losses go recognized by the recipient resident in the residence-country.)

Each cell of the matrix shows the payoffs to both agents when the intersecting strategies (protect/not protect) are played. The source-country's payoff appears as the first number of each pair, the residence-country's as the second (for example in cell B of Table 3 the source-country has a payoff of 4 and the residence-country has a payoff of 0 ). The payoffs are defined here under a Prisoner's Dilemmain that they reflect a situation in which a unilateral strategy is selected by an agent regardless of the strategy of the other agent. $^{49}$

The assumption is that, initially, countries do not communicate and do not have information about reciprocal corporate profits and losses. If the countries, however, were able to communicate, they would be in a position to implement at a cross-border level the same correlative adjustments (deduction by transferor, recognition by recipient) that are achieved at the domestic level when information about domestic corporate profits and losses is fully shared by consolidated companies and national tax authorities. In fact, the exchange of information would enhance tax authorities' enforcement capabilities as both countries would be in a position to prevent the aggressive tax planning techniques that generate their policy concerns (erosion of the national tax base, double use of losses, and creation of artificial profits/losses).

If there is sharing of information on reciprocal corporate profits and losses the two countries can apply correlative adjustments at domestic and cross-border level and there is no risk of arbitrage on asymmetric information by taxpayers. In that situation, deduction of losses could be disallowed only in abusive schemes, for example when losses are artificially created in the source-country and transferred to the residencecountry solely for the purposes of setting them off with corporate profits. So information about reciprocal corporate profits and losses is highly prized by the actors of the game (i.e. residence and source countries. $)^{50}$

In this Prisoner's Dilemma game payoffs are established to reflect the value in the residence and source country of information about reciprocal domestic profits and losses and therefore are determined in these four basic situations.

${ }^{49}$ BAIRD, supra note 14 , at 6-14.

${ }^{50}$ The OECD has repeatedly observed how information is relevant in counteracting aggressive tax strategies. See, e.g., OECD, Hybrid Mismatch Arrangements: Policy And Compliance Issues (2012); OECD, TACKLING AgGressive Tax Planning Through IMPROVED TransParenCy AND DisClosure (2011). 
- $\quad$ There is no exchange of information about reciprocal corporate profits and losses, the source- country protects it own tax base without while the residencecountry does not protect its own tax base (i.e. losses are not deducted in the sourcecountry but are recognized in the residence-country), the payoff for the source-country is 4 (and for the residence-country is 0 );

- $\quad$ There is exchange of information about reciprocal corporate profits and losses, and both countries do not protect their own tax bases (i.e. allow a cross-border correlative adjustment: losses deducted in the source-country are recognized in the residence-country), the payoff for both countries is 3 .

- $\quad$ There is no exchange of information about reciprocal corporate profits and losses, and both countries do not protect their own tax bases (i.e. losses are neither deducted in the source-country nor recognized in the residence-country), the payoff for both countries is 2 (this payoff is lower than 3 because there is no correlative adjustment);

- There is no exchange of information about reciprocal corporate profits and losses, the source-country does not protect its own tax base while the residencecountry country protects it own tax base (i.e. losses are deducted in the source-country but are not recognized in the residence-country), the payoff for the residence -country is 0 (and for the source-country is 4).

Table 3 depicts a Prisoner's Dilemma situation in which each agent unilaterally evaluates its possible actions by comparing the payoffs in each column, since this shows each agent which action is preferable for each possible action by the other agent.

\begin{tabular}{|l|l|l|}
\hline $\begin{array}{l}\text { BOTH COUNTRIES } \\
\text { ADOPT GROUP } \\
\text { RELIEF }\end{array}$ & $\begin{array}{l}\text { RESIDENCE-COUNTRY } \\
\text { PROTECTS TAX-BASE }\end{array}$ & $\begin{array}{l}\text { RESIDENCE-COUNTRY } \\
\text { DOES NOT PROTECT } \\
\text { TAX-BASE }\end{array}$ \\
$\begin{array}{l}\text { Foreign losses not } \\
\text { recognized by the recipient }\end{array}$ & $\begin{array}{l}\text { Foreign losses recognized by } \\
\text { the } \\
\text { recipient }\end{array}$ \\
\hline $\begin{array}{l}\text { SOURCE-COUNTRY } \\
\text { PROTECTS TAX- } \\
\text { BASE }\end{array}$ & $\mathbf{A}$ & $\mathbf{B}$ \\
$\begin{array}{l}\text { Domestic losses not } \\
\text { deductible by } \\
\text { the transferor }\end{array}$ & $\mathbf{2 , 2}$ & $\mathbf{4 , 0}$ \\
\hline $\begin{array}{l}\text { SOURCE-COUNTRY } \\
\text { DOES NOT PROTECT } \\
\text { TAXBASE }\end{array}$ & $\mathbf{C}$ & $\mathbf{D}$ \\
$\begin{array}{l}\text { Domestic losses } \\
\text { deductible by the } \\
\text { Transferor }\end{array}$ & $\mathbf{0 , 4}$ & $\mathbf{3 , 3}$ \\
\hline
\end{tabular}


An example of a Prisoner's Dilemma game in respect to cross-border losses (Table 3)

Let us start with the two situations that give the highest or lower unilateral payoff (cell $\mathrm{B}$ and $\mathrm{C}$ ). In these two situations there is no exchange of information about reciprocal corporate profits and losses. In cell $\mathbf{B}$, the source-country does not recognize the deduction of the losses of domestic affiliated companies, but those losses, after transfer to the recipient, are recognized in the residence-country. In this interaction the source-country fully protects its tax base by not recognizing the outflow of domestic losses (payoff: 4.) The residence-country does not protect its tax base at all; the inflow of foreign losses is not limited because the losses are recognized in the residence-country (payoff: 0.) This interaction is favorable only for the source-country when it acts in such a capacity with a payoff of 4 (but when that country acts as a residence country it will get a payoff of 0.) By contrast, in cell $\mathbf{C}$, the residence-country does not recognize the receipt of transferred losses of a foreign affiliated company, but those losses are deductible by the transferor in the source-country. In this interaction the source-country does not protect its tax base at all because the outflow of foreign losses is not limited, as the losses are deductible in the source-country (minimum payoff: $\mathbf{0}$.) The residencecountry fully protects its tax base by not recognizing the inflow of foreign losses (maximum payoff: 4.) This interaction is favorable only for the residence-country when it acts in such a capacity with a payoff of 4 (but when that country acts as a sourcecountry it will get a payoff of 0 .)

Let us now look at two intermediate situations (cell A and D.) In cell A, neither the residence-country nor the source-country allows, respectively, the deduction (by the transferor) and the recognition (by the recipient) of losses. In this interaction the sourcecountry protects its tax base because the losses are not deductible in the source-country (payoff: 2), and the residence-country protects its tax base by not recognizing the inflow of foreign losses (payoff: 2.) This is not a correlative adjustment because, in light of the fact that there is no exchange of information about reciprocal corporate profits and losses, both countries renounce to apply the group relief based on deduction/recognition of losses.

Finally, cell $\mathbf{D}$ represents the interaction in which both countries cooperate and exchange information on reciprocal corporate profits and losses thereby eliminating information asymmetries. This relies on the assumption that each country can be at times a residence or a source country, so that each country has an incentive to exchange information to better protect its own interests in all cases (i.e. when it acts as a residencecountry and when it acts as a source-country.) As a result, the residence-country and source-country allow, respectively, the deduction (by the transferor) and the recognition (by the recipient) of losses. In this interaction the source-country does not protect its tax base because the losses are deductible in the source-country, but also the residencecountry does not protect its tax base because it recognizes the inflow of foreign losses, and there is exchange of information about reciprocal corporate profits and losses. This interaction ensures an intermediate payoff of $\mathbf{3}$ for both countries. The payoff is higher than that of the interaction of cell A (in which the individual payoff was 2 for each agent) because, in light of the fact that the two countries fully exchange information on reciprocal corporate profits and losses, there is a correlative adjustment (i.e. group relief) in a cross-border situation combined with cooperation in enforcement. 
In the Prisoner's Dilemma described at Table 3, the best unilateral strategy is defined for each country by looking at the payoffs. Let us start with the source-country. If the residence-country does not recognize foreign losses for the recipient, then the source-country gets a payoff of 2 by not allowing the deduction of losses by the transferor (cell A), and a payoff of 0 by allowing the deduction of losses by the transferor (cell C). By contrast, if the residence-country recognizes foreign losses for the recipient, then the source-country gets a payoff of 4 by not allowing the deduction of losses by the transferor (cell B), and a payoff of 3 by allowing the deduction of losses by the transferor (cell D). Therefore the source-country is better off not allowing the deduction of losses by the transferor regardless of what the residence-country does. The residence-country, meanwhile, evaluates its actions by comparing its own payoffs in each row. The residence-country comes to the same conclusion that the source-country does, i.e. that it is better off not recognizing the losses (coming from the foreign transferor) in the hands of the recipient, regardless of what the source-country does.

Wherever one strategy of an agent is superior to another strategy against every possible strategy available to the opponent, the first strategy strictly dominates the second one. The unilateral strategies that intersect at cell A (not allowing the deduction of losses by the transferor in the source-country; not recognizing the foreign losses for the recipient in the residence-country) strictly dominate the other strategy available to each player. The strategies of the source-country and the residence-country in cell A are therefore dominant strategies from an unilateral standpoint. Both agents know this about each other, and thus there is no temptation to depart from these strategies, with the result that both agents will not cooperate by way of a correlative adjustment. The sourcecountry will not allow the deduction of domestic losses by the transferor, and the residence-country will not recognize the foreign losses for the recipient. There is mutual defection as the agents do not cooperate.

The foregoing is just an example of a type of interaction (both countries adopting group relief.) The multiple-entry matrix showing all of the interactions of residence and source countries is not diagrammed here in its entirety for brevity's sake. It suffices to say that there are numerous interactions which are similar to the one depicted in Table 3, in which it unilaterally pays off to adopt an uncooperative strategy based on unilateral dominant strategies. In those cases, each country is indifferent to the unilateral strategy of the other country when deciding which strategy to select.

Consider, for example, a residence-country adopting fiscal unity (consolidation of domestic profits and losses) interacting with a source-country adopting group relief or group contribution (transfer of losses between domestic affiliate companies.) The inflow in the residence-country of foreign profits and losses of affiliated companies located in the source-country is an issue exclusively for the residence-country (i.e. whether these foreign profits and losses should be tax-consolidated by the controlling company), but not for the source country which is indifferent to what the residence-country does. The profits and losses (that for the source-country are domestic profits and losses) are in all cases not subtracted from the national tax base of the source-country, both when the residence-country recognizes them and when it does not. In practice, the dominant strategy of the source-country is to prohibit the deduction of those profits and losses if transferred to a foreign recipient regardless of what the residence-country does. At the same time the dominant strategy of the residence-country is not to recognize the foreign corporate regardless of what the source-country does. 
If one, in turn, in the same interactions, looks at the perspective of the sourcecountry (adopting either group relief or group contribution), then the outflow of domestic profits and losses of affiliated companies located in the source-country is an issue exclusively for the source-country (i.e. whether these domestic profits and losses transferred to foreign affiliated companies should be deductible in the source-country), but not for the residence-country, which is indifferent to what the residence-country does. Those profits and losses (that for the residence-country are foreign profits and losses) are not included in the national tax base of the residence-country in all cases. In practice, the dominant strategy of the residence-country is to prohibit the inflow of those foreign profits and losses in all cases regardless of how the source-country acts and at the same time the dominant strategy of the source-country is not to allow the transfer of domestic profits and losses without regard to what the residence-country does. These two unilateral dominant strategies basically amount to uncooperative behavior from both players: the two countries do not exchange information about reciprocal corporate profits and losses and do not cooperate in enforcement, so there might be cases in which losses are used twice (i.e. are consolidated in the residence-country and in the source-country) or never used (i.e. are not consolidated either in the residence-country or in the sourcecountry).

In these numerous situations, the residence-country and the source-country are unilaterally better off not cooperating, a typical outcome of the Prisoner's Dilemma. The best strategy, in the jargon of game theory, is a strictly dominant strategy that is always worth taking by a single agent from a unilateral perspective, despite the fact that cooperation would lead to a higher payoff for both agents. In this setting, the pair of dominant strategies of the two agents (mutual defection) is said to be the "solution" to the game, which is the unique Nash equilibrium of the game. ${ }^{51}$ The preference for a dominant strategy over a dominated strategy is a minimum requirement of economic rationality. This implies that if a game has an outcome that is a unique Nash equilibrium that must be its unique solution. This is the reason why in most of the interactions of unilateral strategies concerning cross-border profits and losses, countries currently adopt a dominant strategy. In Table 3, that intersection of uncooperative strategies is indicated in cell $\mathrm{A}, \mathrm{B}$, and $\mathrm{C}$, which gives in all cases a total payoff of 4 for an uncooperative behavior of both players, while cell $\mathrm{D}$ gives a total payoff of 6 for a cooperative behavior of both players. That simplified situation is not far from the real setting in which countries do not exchange information about reciprocal corporate profits and losses, and thus do not share common rules in respect to cross-border consolidation of profits and losses, but rather pursue their own policies without communicating/cooperating.

IV. THE COORDINATION OF RESIDENCE AND SOURCE COUNTRIES

BASED ON THE EXCHANGE OF GLOBAL CORPORATE TAX INFORMATION: THE CCCTB MODEL

If the interactions of strictly dominant strategies do not imply exchange of information about reciprocal corporate profits and losses and result in a Prisoner's Dilemma equilibrium, how can countries ever cooperate? The answer is that over

${ }^{51}$ The so called "Nash equilibrium" was introduced in the seminal works by John Nash, Nobel Prize winner in Economics who extended and generalized von Neumann and Morgenstern's pioneering work. A set of strategies is at a Nash equilibrium when it is the case that no agent could improve its payoff, given the strategies of all other agents in the game, by changing its own strategy. This idea is related to the concept of strict dominance: a strategy is a Nash equilibrium strategy only if it is dominant (in other terms no strategy could be a Nash equilibrium strategy if it is strictly dominated). See BAIRD, supra note 14, at 19-24. 
repeated interactions, countries play the role of both source-country and residencecountry, so that communication and the resulting cooperation become possible when countries realize that there is a loss generated by non-cooperation that might be remedied by cooperation, achieved through communication and backed by commitment. Moreover, in the current uncooperative setting of countries that rely only on unilateral dominant strategies that prevent the cross-border shifting of profits and losses, global taxpayers avoid the unilateral rules of those individual countries by using aggressive tax planning that takes advantage of information mismatches. The most effective tool to counteract such abuses and arbitrages is the possibility for countries to fully exchange information of reciprocal corporate profits and losses thereby cooperating in enforcement. In this situation, correlative adjustments linking the domestic methods of tax consolidation become possible in a cross-border situation.

In the model used here, the countries envisage that the interactions will be repeated for an indefinite period of time on the basis of reciprocity and thus engage in some form of agreed-upon coordinated action that leads to the highest possible global payoffs afforded by the game. Relying on the game diagrammed in Table 3, it is easy to see that the highest global payoff that could be achieved is the intersection of strategies in cell D: a cooperative interaction which implies exchange of information that allows cross-border correlative adjustments in which each agent gets a payoff of $3,{ }^{52}$ with a global payoff of $6 . .^{53}$ The initial setting of the Prisoner's Dilemma dictates that such a payoff cannot be achieved because it is not a dominant strategy, but a rational policy maker can identify a way out from that deadlock of non-cooperation. It is therefore possible for countries to achieve the tax regulation of cross-border consolidation of profits and losses through either (i) sets of bilateral agreements, or (ii) a single multilateral agreement, thereby creating an international tax regime. ${ }^{54}$

Bilateral agreements pursue solutions that can be attained by two countries on the basis of reciprocity through agreed-upon correlative adjustments based on the exchange of information about reciprocal corporate profits and losses. Those situations that were described as uncooperative equilibria of the game can thus be transformed into agreedupon cooperative solutions that afford the highest global payoffs. For example, the very same two countries adopting group relief that were stuck in the uncooperative solution of cell A of Table 3, by communicating, can develop inter-dependent agreed-upon mechanisms when the deduction of foreign losses transferred from the source-country to the residence-country (an inflow of foreign losses from the perspective of the residencecountry) is matched by a correlative adjustment in the other country, i.e. the deduction of domestic losses in the source-country (an outflow of domestic losses from the perspective

52 In that cooperative interaction the domestic losses in the source-country are deductible by the transferor, and the foreign losses are recognized by the recipient in the residence-country.

${ }^{53}$ If there is an uncooperative interaction that prevents cross-border correlative adjustments (cell A), then they each get a payoff of 2 . If there is an uncooperative interaction favorable to the source-country (cell B), then the source-country gets a payoff of 4 (full protection of its tax base) and residence-country gets a payoff of 0 (no protection at all of its tax base). The reverse situation occurs when there is an uncooperative interaction favorable to the residence-country (cell C).

${ }^{54}$ The view that there is an actual international law regime that transcends national interests operating in a mere coordination game dominated by unilateral strategies is advocated in REUVEN AVI Yonah, International TAX as International Law supra note 18 at 2-8; Diane M. Ring, Prospects for a Multilateral Tax Treaty, 26 BROOK. J. INT'L LAW 1699 (2001); Hugh Ault, The Importance of International Cooperation in Forging Tax Policy, 26 BROOK. J. InT'L LAw 1693 (2001); Paul R. McDaniel, Trade and Taxation, 26 BROOK. J. INT'L LAW 1621 (2001). 
of the source-country). In this case bona fide transactions would be accepted and arbitrage prevented. For example, the transfer to the residence-country of losses that are artificially created in the source-country solely for the purposes of setting them off with corporate profits would not be allowed.

Similar uncooperative strategies can occur in other combinations of unilateral dominant strategies that can be transformed into cooperative mechanisms. For example, when two countries adopt group contribution the two strategies become inter-dependent agreed-upon strategies when the taxation in the residence-country of the foreign profits transferred from the source-country (an inflow of foreign profits from the perspective of the residence-country) is matched by a correlative adjustment in the other country, i.e. the deduction of domestic profits in the source-country (an outflow of domestic profits from the perspective of the source-country). Similar inter-dependent agreed-upon strategies also occur when two countries exchange information, do not adopt the same system of domestic tax consolidation, but the residence-country adopts elective ITC, mandatory worldwide tax consolidation, or consolidation of foreign PEs. When the residence-country adopts these types of extra-territorial consolidation, and the sourcecountry adopts either group relief or group contribution, the transfer of, respectively, losses or profits from the source-country is matched by a correlative adjustment in the residence-country in the form of a consolidation of those losses or profits by the consolidating company.

These inter-dependent arrangements require bilateral agreements, which in theory could be pursued through protocols to existing tax treaties or by entering ad hoc agreements. This approach might be problematic as clauses that provide for exchange of information about cross-border consolidation of profits and losses are not included in the OECD Model treaty, and therefore a multilateral approach would be more feasible. The CCCTB constitutes a first attempt of such a multilateral approach to the sharing of Corporate Global Tax Information. ${ }^{55}$

The CCCTB is usually seen as a substantive consolidation mechanism of crossborder corporate profits and losses as the consolidated taxable profits are determined in accordance to common EU provisions ${ }^{56}$ on the basis of an all-in-all-out rule which mandates that all the companies of the group which have certain requirements are consolidated. ${ }^{57}$ The tax bases of the members of a group are consolidated by the

${ }^{55}$ In its Explanatory Memorandum within the CCCTB Proposal, supra note 16, at 9, the Commission indeed acknowledged that rules of such a proposed Directive would be ineffective if each Member State applied its own system and that the nature of the subject requires a common approach, basically on three grounds, as single set of rules is needed (i) for computing, consolidating and sharing the tax bases of associated enterprises across the Union, (ii) for affording cross-border loss relief, tax-free intragroup asset transfers and the allocation of the group tax base through a formula, and (iii) for simplifying administrative procedures.

${ }^{56}$ According to Articles 6(1) and 104(1) of the CCCTB Proposal. Id. On the election mechanism, see Johanna Hey, CCCTBOptionality, in LANG ET AL., COMMOn CONSOlIDATED CORPORATE TAX BASE, supra note 17 , at $93-114$.

57 The perimeter is defined by Articles 54 and 55. Article 54 defines qualifying subsidiaries as immediate and lower-tier subsidiaries in which the parent company holds: (a) a right to exercise more than $50 \%$ of the voting rights; and (b) an ownership right amounting to more than $75 \%$ of the company's capital or more than $75 \%$ of the rights giving entitlement to profit. Article 55 deals with the formation of groups and provides that a resident taxpayer shall form a group with: (a) all its PEs located in other Member States; (b) all PEs located in a Member State of its qualifying subsidiaries resident in a third country; (c) all its qualifying subsidiaries resident in one or more Member States; (d) other resident taxpayers which are qualifying subsidiaries of the same company which is resident in a third country and fulfils the conditions of 
consolidating company, and when the consolidated tax base is negative, the loss is carried forward and set off against the next positive consolidated tax base (Article 56). By contrast, the positive consolidated tax base is apportioned among the countries of the consolidated companies in accordance with a formula based on assets, sales, and labor (Articles 86 to 102). ${ }^{58}$ So the CCCTB model treats the group as a single entity for tax purposes. ${ }^{59}$ This is achieved by relinquishing the principle of tax deferral with regard to the tax positions (profits or losses) of foreign controlled companies. ${ }^{60}$ Game theory however shows that the CCCTB can be viewed as a multilateral method for the exchange of Global Corporate Tax Information at the EU level because it amounts to an institutional framework that relies on qualified corporate intermediaries - the consolidating and consolidated companies - and allows the full availability of Global Corporate Tax Information at a regional (EU) level.

In terms of information sharing the CCCTB in fact operates as follows. Each single participant opts for the CССТВ by giving notice to the competent authority of the Member State in which it is resident, and the consolidating company gives notice to the tax authority of its country of residence, which becomes the principal tax authority. ${ }^{61}$ Each participant company files its tax return with the competent authority of its country of residence, while the consolidating company files the consolidated tax return with the principal tax authority in its country of residence. ${ }^{62}$ The consolidated tax return includes all relevant Global Corporate Tax Information, inter alia, the identification of all group members, the calculation of the tax base of each group member and of the consolidated tax base, and the calculation of the apportioned share/ tax liability of each group member. ${ }^{63}$ The consolidated tax return and supporting documents filed by the consolidating company are stored on a central database to which all the competent authorities have access, but also each participant company keeps records and supporting documents in sufficient detail for audits to be carried out and provides all information relevant to the determination of its tax liability. ${ }^{64}$

Article 2(2)(a). See Jan van de Streek, The CCCTB Concept of Consolidation and the Rules on Entering a Group, 40 INTERTAX 24-32 (2012); Mario Tenore, Requirements to Consolidate and Changes in the Level of Ownership, in LANG ET AL., COMMON CONSOLIDATED CORPORATE TAX BASE, supra note 17, at 465-84.

58 Articles 86 to 102 of the CCCTB Proposal, supra note 16, at 49, 55. See also CCCTB Proposal, supra note 16, at 5 (Explanatory Memorandum). On the apportionment mechanism in general see Michael Kobetsky, The Case for Unitary Taxation of International Enterprises, 62 BULL. INT'L TAX. 201-15 (2008); Louis Thomas Marchlen, Selected Issues on Interstate Apportionment of Corporation Income Tax in the US: A Model for Europe?, 38 INTERTAX 163-66 (2010).

${ }^{59}$ According to Article 103 the tax liability of each group member is the outcome of the application of the national tax rate to the apportioned share, adjusted according to Article 102 (items deductible against the apportioned share), and further reduced by the deductions provided for in Articles 76 (interest and royalties and any other income taxed at source. CCCTB Proposal, supra note 16, at 44, 55.

${ }^{60}$ According to Article 57 the tax bases of the members of a group are consolidated, and when the consolidated tax base is negative, the loss is carried forward and are set off against the next positive consolidated tax base. CCCTB Proposal, supra note 16, at 38. When the consolidated tax base is positive, it is shared in accordance with Articles 86 to 102 (apportionment of the consolidated tax base). CCCTB Proposal, supra note 16, at 49-55. See Valerio Antonelli \& Raffaele D'Alessio, From Consolidated Profitand-Loss Account to Group Tax Base: a CCCTB Perspective, in LANG ET AL., COMMON CONSOLIDATED CORPORATE TAX BASE, supra note 17, at 485-517.

${ }^{61}$ Article 74 of the CCCTB Proposal, supra note 16, at 43.

62 Article 109 of the CCCTB Proposal, supra note 16, at 57.

${ }^{63}$ Article 110 of the CCCTB Proposal, supra note 16, at 57.

${ }^{64}$ Articles 115 and 117 of the CCCTB Proposal, supra note 16, at 60. 
The CCCTB also introduces significant simplifications for groups operating at a pan-EU level that are essentially a consequence of the sharing of Global Corporate Tax Information by the participating countries. ${ }^{65}$ These simplifications are attained by taxneutralizing intra-group transactions in three major areas. First, under the CCCTB Proposal rules, cross-border transfers of shares/assets of companies belonging to the group do not lead to the recognition of taxable capital gains and losses, as these gains and losses are recognized only when shares/assets are sold by a company of the group to third parties. ${ }^{66}$ Second, the CCCTB Proposal recognizes that intra-group cross-border dividends are exempt for the recipient corporate shareholder to prevent double taxation. ${ }^{67}$ Third, the CCCTB Proposal neutralizes aggressive transfer pricing techniques because in such a multi-country consolidation there is no need to shift profits from high to low tax jurisdictions, a feature drawn from the European experience that may inspire the U.S. to adopt worldwide tax consolidation. ${ }^{68}$

Unfortunately, a multilateral solution like the CCCTB, in the form of a directive, is not feasible in the EU context as it would require the unanimous consent of 27 Member States. There is, however, a possibility that the CCCTB will be approved through enhanced cooperation. Enhanced cooperation would require a minimum of nine Member States. ${ }^{69}$ The evolutionary argument that is advanced here is therefore the following: should the path of enhanced cooperation be pursued, approval would be facilitated by the fact that a set of common operative rules of consolidation of cross-border profits/losses

65 The Explanatory Memorandum of the CCCTB Proposal, supra note 16, remarks that businesses operating across national borders will benefit both from the introduction of cross-border loss compensation and from the reduction of company tax-related compliance costs, and notes that allowing the immediate consolidation of profits and losses for computing the EU-wide taxable bases is a step toward reducing overtaxation in cross-border situations and thereby towards improving the tax neutrality conditions between domestic and cross-border activities to better exploit the potential of the Internal Market.

${ }^{66}$ In respect to the Explanatory Memorandum of the CCCTB Proposal, supra note 16, the Commission has noted that a key obstacle in the single market today involves the high cost of complying with transfer pricing formalities using the arm's length approach, and that transaction-by-transaction pricing based on the "arm's length" principle may no longer be the most appropriate method for profit allocation.

${ }^{67}$ According to Article 11(c) and (d) of the CCCTB Proposal received profit distributions and proceeds from a disposal of shares are exempt from corporate tax. CCCTB Proposal, supra note 16, at 22. Article 59(1) also provides that in calculating the consolidated tax base, profits and losses arising from transactions directly carried out between members of a group are ignored. CCCTB Proposal, supra note 16, at 39 .

${ }^{68}$ On the critical aspects of transfer pricing in the U.S. market see Reuven S. Avi-Yonah, Between Formulary Apportionment and the OECD Guidelines: A Proposal for Reconciliation, 2 WORLD TAX J. 3, 3-5 (2010); Reuven S. Avi- Yonah, The Rise and Fall of Arm's Length: A Study in the Evolution of U.S. International Taxation, 15 VA. TAX REv. 89 (1995); Yariv Brauner, Cost Sharing and the Acrobatics of Arm's Length Taxation, 38 InTERTAX 554 (2010): Yariv Brauner, Value in the Eye of the Beholder: The Valuation of Intangibles for Transfer Pricing Purposes, 28 VA. TAX REV. 79 (2008); Michael C. Durst, It's Not Just Academic: The OECD Should Reevaluate Transfer Pricing Laws, 57 TAX Notes InT'L 247 (2010); Michael C. Durst, The Two Worlds of Transfer Pricing Policymaking, 61 TAX Notes INT'L 439.

${ }^{69}$ See, e.g., Eric Kemmeren, CCCTB Enhanced Speed Ahead for Improvements, 39 INTERTAX 20811 (2011); Leon Bettendorf, Albert Van Der Horst, Ruud A. De Mooij \& Hendrik Vrijburg, Corporate Tax Consolidation and Enhanced Cooperation in the European Union, 31 FISCAL STUD. 453-79 (2010); Nerudovà Danuse, The Possible Introduction of CCCTB via Enhanced Cooperation: Some Open Issues, 46 EUR. TAX'N 187-96 (2006); Bob van der Made, European Union: A New Dawn for Further EU Tax Harmonization, 22 INT'L TAX REV. 45 (2011); Hendrik Vrijburg, 50 years of EU Corporate Income Tax Harmonization Initiatives: Is Enhanced Cooperation the Solution? (Sep. 29, 2011) (unpublished Ph.D. dissertation), available at http://repub.eur.nl/res/pub/26838/Thesis_Vrijburg.pdf; Leon Bettendorf, Michael P. Devereux, Albert Van der Horst, Simon Loretz \& Ruud De Mooij, Corporate Tax Harmonization in the EU, 25 ECON. POL'Y 537-90 (2010). 
among a sufficient number of Member States (at least nine) has already emerged. ${ }^{70}$ Those Member States that already have common rules in this area would be willing to enter into a multilateral binding directive, thereby overcoming the current uncooperative situations that have been highlighted in section 3, using the Prisoner's Dilemma approach. A multilateral agreement would overcome the need for unanimous consensus among a higher number of parties (all 27 Member States) required for the approval of EU Directives. $^{71}$

\section{THE EXTENSION OF THE CCCTB AS A MULTILATERAL TREATY ON EXCHANGE OF GLOBAL CORPORATE TAX INFORMATION}

As there is currently no established method for sharing Global Corporate Tax Information, the US like other countries has resorted to unilateral strategies to regulate US global firms' use of profits and losses. The US thus interacts with other countries in an environment in which such information is a strategic asset for effective tax enforcement. In respect to corporate cross-border profits and losses, the US acts as a residence-country and at times as a source-country. When the US acts as a residencecountry, it limits the extraction of the national base by US firms who employ techniques to import foreign profits and losses to parent companies in the US. By contrast, when the US acts as a source-country, it limits the extraction of national base carried by non-US firms through consolidation techniques in which US profits or losses from affiliated companies located in the US are transferred to parent companies located abroad.

In both cases the US can be the target of aggressive strategies pursued by global taxpayers, resulting in the erosion of the US tax base, double use of losses, and artificial creation of profits/losses. Therefore the US could protect its national interests by exchanging information concerning those situations in all cases (i.e. when it acts as a residence-country and when it acts as a source-country). This could be achieved by access to Global Corporate Tax Information through a multilateral system which would allow the US to counteract more effectively those strategies pursued by US-based global taxpayers that exploit asymmetries of information and various kinds of mismatches.

It is worth considering the current US regime and how it could be improved by exchange of information in respect to cross-border profits and losses of foreign branches and affiliated companies. The US currently uses a domestic approach to fiscal unity ${ }^{72}$ and therefore when it acts as a residence-country, the corporate losses of foreign affiliates are not recognized in the US, in line with the principle of tax deferral. ${ }^{73}$ The same

\footnotetext{
${ }^{70}$ In respect to the concept of "operative rules," see Carlo Garbarino, An Evolutionary Approach to Comparative Taxation, 57 AM. J. ComP. L. 677 (2009).

${ }^{71}$ Consolidated Version of the Treaty on the Functioning of the European Union art. 113, May 9, 2008, 2008 O.J. (C 115) 47.

${ }^{72}$ See supra note 20.

${ }^{73}$ On the principle of tax deferral see Reuven S. Avi-Yonah, Globalization, Tax Competition, and the Fiscal Crisis of the Welfare State, 113 Harv. L. REv. 1573 (2000); Reuven S. Avi-Yonah, Obama's International Tax Plan a Major Step Forward, 123 TAX Notes 735 (2009); U.S. TREASURy DeP't, The Deferral of Income Earned Through U.S. Controlled Foreign Corporations: A Public Study (2000), available at http://www.treasury.gov/resource-center/tax-policy/Documents/subpartf.pdf; Robert J. Peroni, J. Clifton Fleming, Jr. \& Stephen E. Shay, Getting Serious About Curtailing Deferral of U.S. Tax on Foreign Source Income, 52 SMU L. REV. 455 (1999); Reuven S. Avi-Yonah, Comment on Peroni, Fleming and Shay, "Getting Serious About Curtailing Deferral of U.S. Tax on Foreign Source Income”, 52 SMU L. REv. 531 (1999); Reuven S. Avi-Yonah, To End Deferral as We Know It: Simplification Potential of Checkthe-Box, 74 TAX NOTES 219 (1997); Asim Bhansali, Globalizing Consolidated Taxation of United States Multinationals, 74 TEX. L. REv. 1401 (1996); J. Clifton Fleming, Jr. \& Robert J. Peroni, Reinvigorating Tax Expenditure Analysis and Its International Dimension, 27 VA. TAX REV. 437 at 528-41 (2008); Robert J.
} 
approach is adopted for branches with the "branch loss recapture rules" under which the losses of a foreign PE cannot be deducted against US-source income, except to the extent that they exceed foreign source income generated by the taxpayer's profitable foreign PEs. $^{74}$

With the privilege of deferral, a US person can conduct profitable business or investment activities through a company located in a country where corporate taxes are lower than in the US (most countries qualify because the US corporate rate is one of the highest) without paying US residual tax until the foreign corporation distributes its profits and foreign losses are not recognized in the US. ${ }^{75}$ Thus, US shareholders can defer substantial amounts of US residual taxes and reinvest those amounts in foreign operations but cannot directly use foreign corporate losses. The current US regime of elective deferral, combined with anti-deferral limitations (such as the Subpart F rules), has traditionally been presented as the balancing of capital export neutrality ("CEN") ${ }^{76}$ and international competitiveness objectives ${ }^{77}$ but lately it has been shown that the deferral privilege ends up operating as a tax "subsidy" that rewards US persons who locate corporate operations in low-tax foreign countries. The result: the deferral may operate to exempt entirely US low-taxed income until that income is repatriated. ${ }^{78}$

Peroni, Deferral of U.S. Tax on International Income: End It, Don't Mend It-Why Should We Be Stuck in the Middle with Subpart F?, 79 TEx. L. REV. 1609 (2001); Robert J. Peroni, The Proper Approach for Taxing the Income of Foreign Controlled Corporations, 26 BROOK. J. INT'L L. 1579 (2001); H. David Rosenbloom, From the Bottom Up: Taxing the Income of Foreign Controlled Corporations, 26 BROOK. J. INT'L L. 1525 (2001); Stephen E. Shay, Revisiting U.S. Anti-Deferral Rules, 74 TAXES 1042 (1996).

${ }^{74}$ I.R.C. $§ 904(f)(5)$ (2012). A similar rule is found in Germany and has be the focus of an ECJ case. Case C-415/06, SEW (Stahlwerk Ergste Westig) GmbH, 2007 E.C.R. I-0015.

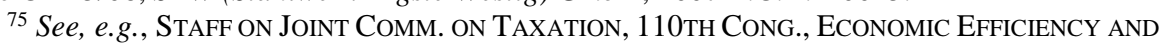
Structural Analyses of Alternative U.S. Policies for Foreign Direct InVeSTMent 3, 14 (2008); Charles H. Gustafson, Robert J. Peroni \& Richard Crawford Pugh, TAXation of International TRANSACTIONS 3, 21-2, 443-45 (2006).

${ }^{76}$ The CEN standard was originally based on the idea that the efficiency should be evaluated from a worldwide welfare perspective by ensuring production efficiency which implies convergence of pretax returns; see PEGGY BREWER RICHMAN, TAXATION OF FOREIGN INVESTMENT INCOME: AN ECONOMIC ANALYSIS (1963); Peggy B. Musgrave, United States Taxation of Foreign Investment Income: Issues and ARguments (1969); Rosanne Altshuler, Recent Developments in the Debate on Deferral, 87 TAX NoTES 255 (2000). CEN is defined by Devereux as a standard that "implies that $(a)$ the international tax system will not distort the location decisions of any individual investor, $(b)$ the pretax rate of return in all jurisdictions will be the same (production will be efficiently organized), but $(c)$ investors in different jurisdictions may face different post-tax rates of return on their investment, and hence different incentives to save." Michael P. Devereux, Taxation of Outbound Direct Investment: Economic Principles and Tax Policy Considerations, 24 OXFORD REV. ECON. POL'Y 698 at 701 (2008).

77 See Nat'l Foreign Trade Council, International Tax Policy for the 21 st Century 56, 59, 93, 126 (2001); U.S. Treasury Dep't, The Deferral of Income Earned Through U.S. CONTROLled ForEIGN CORPORATIONS, see supra note 74, at 22; U.S. TREASURY DEP'T, INTERNATIONAL TAX REFORM: AN INTERIM REPORT 7-8 (1993); 1 U.S. TREASURY DEP'T, TAX REFORM FOR FAIRNESS, SiMPLICITY, AND ECONOMIC GROWTH 142 (1984), available at http://www.treasury.gov/resource-center/taxpolicy/Documents/tres84v1All.pdf. The commentators that disfavor tax deferral are concerned with capital export neutrality and/or locational neutrality. See, e.g., Reuven S. Avi-Yonah, The Logic of Subpart F: A Comparative Perspective, 79 TAX Notes 1775 (1998); Stephen E. Shay, Revisiting U.S. Anti-Deferral Rules, see supra note 74, at 1061, 1063.

78 See: J. Clifton Fleming, Jr., Robert J. Peroni \& Stephen E. Shay, Worse than exemption, 59 EMORY L. J. 79, 96-98 (2009); STAFF OF JoInT COMM. ON TAX'N, Alternative Policies, supra note 76, at 16; Terrence R. Chorvat, Ending the Taxation of Foreign Business Income, 42 ARIZ. L. REv. 835, 844 (2000). 
This has generated a so called "lock-out effect," i.e. US multinationals keep their profits abroad because of the tax benefits of deferral. ${ }^{79}$ Studies by economists have evaluated various issues related to this situation, such as restraints on management's ability to absorb cost resources and problems for shareholders trying to optimize their portfolios. ${ }^{80}$ There is no extant evidence that US multinationals face a capital constraint caused by the lock-out effect, but the cost of deferral is rapidly increasing because firms are running out of feasible ways to reinvest the sums accumulated abroad. ${ }^{81}$ Lock-out effects are less relevant for other OECD countries which adopt an exemption on foreign un-repatriated corporate profits that does not incentivize retention of those profits abroad.

Since the US adopts fiscal unity (consolidation of domestic profits and losses), when it interacts with source-countries that also unilaterally adopt a domestic tax consolidation system (such as fiscal unity, group relief or group contribution) the result is a Prisoner's Dilemma where uncooperative strategies prevail (described supra at section 3.) For example, when the US is interacting with a source-country adopting group relief (transfer of losses between domestic affiliate companies) such as the UK, the inflow in the US of UK corporate profits and losses of affiliated companies located in the UK is not allowed and the US treatment is not interdependently linked to the UK treatment of losses. Those profits and losses (that for the UK are domestic profits and losses) are in all cases not deducted from the UK tax base. In practice in a Prisoner's Dilemma situation the dominant strategy for the US is not to recognize the UK corporate profits and losses regardless of what the UK does. At the same time, the dominant strategy of the UK is to prohibit the deduction of those profits and losses if transferred to a US recipient regardless of what the US does. These two unilateral dominant strategies amount to an uncooperative behavior of both players: the US and UK do not exchange information about reciprocal corporate profits and losses and do not cooperate in enforcement, so there might be cases in which the UK losses are used twice (i.e. are consolidated in the US and in the UK) or never used (i.e. are not consolidated either in the US or in the UK). This is an example of a recurrent situation: when the US interacts with unilateral strategies of other source-countries, it is stuck in an uncooperative outcome that does not include the exchange of information on corporate profits and losses.

However, in some cases the US system unilaterally allows a certain amount of consolidation of foreign corporate profits and losses by adopting a variation to a worldwide consolidation approach referred to as international tax consolidation ${ }^{82}$. First, the US essentially adopts the consolidation approach for the profits of branches, as it purports to tax foreign-source business income at the same rates that apply to US-source

79 The accumulated earnings of foreign subsidiaries of U.S. resident parent companies totaled roughly \$1 trillion in 2008 and today total approximately \$1.4 trillion, after net extraordinary dividends in 2005 of about $\$ 312$ billion in response to the one-year repatriation tax holiday offered by Internal Revenue Code section 965. See ECONOMIC RECOVERY ADVISORY BOARD, THE REPORT ON TAX REFORM OPTIONS 82, available at www.whitehouse.gov/sites/default/files/microsites/PERAB_Tax_Reform_Report.

${ }^{80}$ See A. Desai \& James R. Hines Jr., Old Rules and New Realities: Corporate Tax Policy in a Global Setting, 57 NAT'L TAX. J. 937 (2004); Harry Grubert, Comment on Desai and Hines, "Old Rules and New Realities: Corporate Tax Policy in a Global Setting”, 58 Nat'L TAX. J. 263 (2005); Mihir A. Desai \& James R. Hines, Jr., Reply to Grubert, 58 NAT'L TAX. J. 275 (2005).

${ }^{81}$ Lisa Bryant-Kutcher, Lisa Eiler \& David A. Guenther, Taxes and Financial Assets: Valuing Permanently Reinvested Foreign Earnings, 56 NAT'L TAX. J. 699, 702-03 (2008); Edward D. Kleinbard, Stateless Income, supra note 1 at 767.

${ }^{82}$ See supra section 2. 
business income. This suggests that foreign-source losses should be deductible against US-source corporate profits. So when the so called "branch loss recapture rules" do not apply, US taxpayers are encouraged to concentrate loss-generating activities in foreign PEs, as the losses are passed through directly to the US. Once foreign activities become profitable, US taxpayers are encouraged to transfer those activities to controlled foreign corporations, in order to defer US tax on the foreign-source income. ${ }^{83}$ Second, foreign corporate losses and other deductions may be transferred to the US domestic tax jurisdiction by multinational firms that thereby capture "tax rents." 84 The result is that the system morphs into a territorial system as the deferral becomes a final exemption that incentivizes companies to refrain from distributing dividends back to the US and allows the use of foreign corporate losses through purposeful tax planning. ${ }^{85}$

There are different ways in which these tax rents are achieved. For example, interest expenses attributable to a foreign subsidiary are deducted both in the country of the subsidiary and in the US (country of residence of the company) by applying the "check-the-box" rules. ${ }^{86}$ According to those rules, an eligible person that has but one owner, and which elects pass-through treatment, is disregarded as a separate entity for US federal tax purposes. Its activities are treated as a sole proprietorship, branch, or division of its owner. ${ }^{87}$ As a result, US firms are allowed to bypass Subpart F rules by electing, solely for US tax purposes, to treat a foreign corporate subsidiary as a tax-transparent vehicle, rather than a separate taxable person to which the rules of subpart $\mathrm{F}$ might apply. ${ }^{88}$ In practice, check-the-box rules allow attribution of foreign corporate profits or losses by electing transparency of foreign vehicles. In such schemes, losses attributable to a foreign transparent vehicle are available to offset income of the parent company, but at the same time the transparent vehicle may also deduct the interest expense against the income of other companies resident in the same country. ${ }^{89}$

Another example of a tax rent that leads to the creation of losses in the US acting as the residence-country, is when US companies deduct costs in the US which are not

83 These schemes are counteracted by the so-called "branch loss recapture rules," according to which prior losses of the PE are attributed to the US parent when the PE's assets are transferred to a controlled foreign company. See I.R.C. § 367(a)(3)(C)(2012); Treas. Reg. § 1.367(a)-6T (2013); BorIS I. BitTKer \& James S. Eustice, Federal InCOME TaXation of Corporations and Shareholders II 15.81[1][C] (7th ed. 2006); Charles H. Gustafson, Robert J. Peroni \& Richard Crawford Pugh, TAXATION OF INTERNATIONAL TRANSACTIONS, supra note 76, at 15.

${ }^{84}$ Competition among source-countries pushes multinational firms to move taxable profits from high-tax to low-tax jurisdictions while, at the same time, securing high-tax country pre-tax returns. This implies that multinational firms, but not wholly-domestic firms, can capture the higher pre-tax returns found in high-tax countries, but pay low taxes on them by shifting the locus of taxation of those high pre-tax returns to a low-tax jurisdiction. On this concept of "tax rents," see Kleinbard, supra note 1, at 752-57 (2011).

${ }^{85}$ See Kleinbard, supra note 1, at 716-27 (2011); J. Clifton Fleming, Jr. et al., supra note 79. On the exemption as a relief from double taxation of foreign income see Yariv Brauner, An International Tax Regime in Crystallization, 56 TAX L. REv. 259, 284-87 (2003); GUSTAFSON ET. AL., supra note 76, at 15.

${ }^{86}$ On these aspects see Robert J. Peroni, Steven A. Bank \& Glenn E. Cove, Cases And MATERIALS ON TAXATION OF BUSINESS ENTERPRISES 40-48, 804-21 (4th ed. 2012).

${ }^{87}$ When a check-the-box election is made in respect of a wholly-owned subsidiary, the subsidiary is referred to as a "disregarded entity" because its separate juridical status is ignored for all U.S. tax purposes as the subsidiary is treated as an extension of its sole corporate owner.

${ }^{88}$ See Offshore Profit Shifting and the U.S. Tax Code - Part 1 and 2, supra note 9.

${ }^{89}$ Treas. Reg. $§ 301.7701-3$ (2006). Before 1997, most interest income (or other income items deducted by the payor) earned by a foreign subsidiary domiciled in a low-tax jurisdiction were characterized as subpart F and therefore were taxed immediately in the U.S. See also OECD, supra note 4, at 58. 
related to profits taxable in the countries where the deduction is claimed. ${ }^{90}$ For example, a multinational firm's systematic use of domestic borrowing erodes the US corporate tax base because the firm's interest expense is deductible in the US, while the resulting foreign corporate profits are not accounted for, because of deferral. In practice, taxation on profits is deferred, while deduction of related costs is anticipated through an arbitrage mechanism in which the costs that generate exempt profits are deducted. ${ }^{91}$ So the fact that in certain cases the US law allows deductions properly allocated to un-repatriated, foreign-source income enhances the deferral benefit by producing a worse-thanexemption negative tax rate. ${ }^{92}$ To counteract this phenomenon, as well as the lock-out effect, the President's 2005 Advisory Panel on Tax Reform proposed an exemption for active foreign-source income. Symmetrically, the Panel's proposal would disallow domestic deductions for costs directly allocated to exempt foreign-source income, as well as interest (allocated under a worldwide apportionment approach) and overhead expenses allocated to exempt foreign-source income. ${ }^{93}$

When the US in all the instances described above allows effective consolidation in the US of foreign corporate profits and losses, and interacts with a country that is adopting a domestic tax consolidation system which unilaterally protects its own tax base, the US has a dominant unilateral strategy which may not protect US tax base. For example if the source-country does not allow the transfer of domestic profits and losses (this respectively occurs in group contribution and group relief), those foreign corporate profits and losses are recognized by the US irrespective of what the source-country does. Because in these cases there is no exchange of information with the other country about reciprocal corporate profits and losses, there can be dual use of losses (for example losses are used in the source-country and also consolidated in the US, or foreign profits are exempted but related costs are deductible in the US). As a result, the US and other countries that use fiscal unity are targeted by taxpayers that "double dip" by using profits and losses locally in the source-country and then use those same profits and losses again while consolidating in the US (residence-country).

The US, however, is not always a residence-country in respect to cross-border profits and losses. It acts as source-country when foreign investors establish PEs or affiliated/controlled companies in the US. US corporate profits and losses may be used to achieve tax optimization at global level, in certain cases with a detrimental effect for the US. In those situations the US lacks an effective strategy to prevent the double use of losses generated within the US. The reason for this is that the domestic fiscal unity approach adopted in the US does not include rules that prevent the use of domestic

\footnotetext{
${ }^{90}$ See, for example, Offshore Profit Shifting and the U.S. Tax Code - Part 1 and 2, supra note 9.

${ }^{91}$ On the mismatch between exempt profits and deductible costs see: Harry Grubert \& Rosanne Altshuler, Corporate Taxes in the World Economy: Reforming the Taxation of Cross-border Income, in Fundamental TAx Reform: Issues, Choices, And ImPliCATions 319, 328 (John W. Diamond \& George R. Zodrow eds., 2008); Michael J. Graetz \& Paul W. Oosterhuis, Structuring an Exemption System for Foreign Income of U.S. Corporations, 54 NAT'L TAX J.771, 781 (2001).

92 Clifton Fleming, Jr. et al., supra note 79, at 116.

93 The National Foreign Trade Council, Comments to the President's Advisory Panel on TAX REFORM, available at http://govinfo.library.unt.edu/taxreformpanel/comments/_files/USInternationalTaxSystem.pdf, at 102-105, 132-35, 239-43. See also Harry Grubert, Enacting Dividend Exemption and Tax Revenue, 54 NAT'L TAX J. $811(2001)$.
} 
corporate profits and losses in another residence-country and, as a result, the US is not capable of cooperating with residence-countries to prevent the dual use of losses. ${ }^{94}$

When acting as a source-country, this problem is exacerbated when the US, as a resident-country, also interacts with source-countries that adopt domestic fiscal unity because also in that case there can be dual use of losses.

In conclusion, if there is no exchange of information and the US acts as a residence-country in respect to cross-border corporate profits and losses, the US cannot fully protect its tax base. Likewise, if there is no exchange of information and the US acts a source-country, it cannot cooperate with other countries to prevent the double use of corporate profits and losses. In both cases the reason for the lack of coordination is that the US is stuck in uncooperative outcomes which do not allow access to Global Corporate Tax Information. There is clearly a need to recalibrate the US system of taxation of multinational groups to limit aggressive tax strategies by global taxpayers and the US could effectively pursue that goal by seeking access to Global Corporate Tax Information. The political process leading to a change of the status quo of the tax treatment of US-based multinationals is, at best, unpredictable at this stage. However, assuming that a consensus could be reached on a change of the current situation, the broad policy choice would be, in theory, between a worldwide tax consolidation system and a territorial tax system. These alternatives will not be discussed in details here, but the point is that, although each of these alternatives adopts a radically different solution to the tax treatment in the US of cross-border corporate profits and losses, under both of them the US would have an incentive gain access to Global Corporate Tax Information.

A worldwide tax consolidation system would fully include foreign corporate profits and losses, on a current basis, in the taxable base of the US, net of related expenses, and provide relief from double taxation through a foreign tax credit. This system would require the rollback of the existing deferral principle because foreign corporate profits and losses would be included in the US taxable base on a current basis, and subject to the same U.S. corporate tax rate. Worldwide consolidation would therefore need to include rules to prevent effective corporate inversions. The major issue with mandatory worldwide consolidation is the tax competitiveness of US firms because US firms would face the same US tax rate everywhere and they would not enjoy the same after-tax rate of return on investment reaped by their competitors in source-countries when those competitors are ultimately exempt in their residence-countries that adopt the territorial system. ${ }^{95}$

${ }^{94}$ Other source-based consolidation system have an outright prohibition of extraction of corporate profits and losses. For example in group relief (UK and Ireland) there is a prohibition to transfer all kinds of profits to all kinds of entities and a prohibition to transfer domestic corporate losses to foreign affiliate companies. By the same token in group contribution (Sweden and Finland) there is a prohibition to transfer all kinds of losses to all kinds of entities and a prohibition to transfer domestic corporate profits to foreign affiliate companies.

${ }^{95}$ It is however reasonable to expect that, once the impact of aggressive tax planning that erodes the US base is significantly limited by a worldwide consolidation approach, a convergence of after-tax returns would intervene. In a scenario dominated by tax competition among source-countries in which one residence-country, such as the US, fully adopts a single rate for worldwide consolidated profits that is aligned with median weighted average tax rates, after-tax returns on net business income would in fact tend to converge around a single global rate, so that both CEN and CON would be satisfied from the perspectives of the US. CEN would be satisfied because US firms would face the same after-tax returns everywhere and CON would be satisfied because in source-countries foreign and domestic investors would face the same after-tax opportunities. 
Mandatory worldwide consolidation, however, offers some important advantages over the current system of deferral in respect to the tax treatment of cross-border corporate profits and losses. ${ }^{96}$ First, as worldwide consolidation would include both foreign corporate profits and losses, it would cure the current asymmetry in which foreign corporate profits are includable in the US tax base when repatriated, while foreign corporate losses are not directly recognized. ${ }^{97}$ Second, worldwide consolidation would address aggressive tax strategies that are aimed at the erosion of the US corporate tax base for the simple reason that profits shifted to low-tax foreign jurisdictions would still be taxed in the US, i.e. the country of residence of the consolidating company. Third, worldwide consolidation would dismantle the idiosyncratic US mechanism in which repatriations of foreign profits as dividends is, in practice, prevented because those profits would be taxed in the US (i.e. the country of residence of the consolidating company) regardless of their repatriation as dividends, while foreign losses would be generally deductible. Fourth, worldwide consolidation would mitigate the problem of expense allocations because it would allow the deduction of domestic and foreign expenses attributable to taxable income. Finally, worldwide consolidation would solve transfer pricing problems, because there would be no advantage in using aggressive transfer pricing strategies to move profits from the US to low-tax foreign affiliates.

The tax erosion of the US corporate base is endogenously created by the US through the compounded effect of the deferral system and the erosion techniques pursued by US global firms. ${ }^{98}$ So, the US is in a position to reverse that situation unilaterally, without the need to negotiate the apportionment of profits and losses with other countries (and this implies that the US does not have to rely on multilateral approaches on the apportionment of tax base, such as that adopted by the CCCTB.) The fact that in the OECD area the US is the residence-country whose corporate tax base is most eroded by aggressive tax strategies of its own multinational firms ${ }^{99}$ is a major reason for the US to introduce a worldwide tax consolidation system rather than a territorial one.

The worldwide tax consolidation option certainly would provide a systemic approach to the tax treatment in the US of cross-border corporate profits and losses, but obviously faces major political hurdles mainly in respect to the tax competiveness issues, so that the policy debate recently has shifted to the other basic overhaul option, the territorial tax system. ${ }^{100}$ A territorial system would in theory fully disallow the consolidation of foreign corporate profits and losses and the expenses related to such exempted income and therefore would align the US with the strategies adopted by most EU countries which exempt repatriated dividends by loosely relying on "capital import

${ }^{96}$ For an analysis of mandatory worldwide tax consolidation see Kleinbard, supra note 1, at 152-71

97 Both the territorial system and worldwide tax consolidation attain symmetry in respect to foreign corporate profit and losses, as in the former case they are both excluded, and in the latter case they are both included.

${ }^{98}$ Data can be found in Offshore Profit Shifting and the U.S. Tax Code-Part 1 and Part 2, supra note 9 .

${ }^{99}$ On such techniques see Kleinbard, supra note 1, at 728-49; Clifton Fleming, Jr. et al., supra note 79 , at $110-45$. Differently from the situation in the EU area, in the U.S. there is almost complete overlap between the residence of ultimate parent companies (barring corporate inversions) and the residence of the effective shareholders, and thus worldwide corporate taxation in the U.S. can be viewed as a form of worldwide taxation of the firm's individual owners resident in the U.S.

${ }^{100}$ See, e.g., Harry Grubert \& Rosanne Altshuler, Fixing the System: An Analysis of Alternative Proposals for the Reform of International Tax (April 1, 2013) (unpublished manuscript), available at http://papers.ssrn.com/sol3/papers.cfm?abstract_id=2245128. 
neutrality" ("CIN".) ${ }^{101}$ In a territorial system US residents would be treated differently depending on the location of their income but would compete with foreign companies in the source-country at the same tax rates. ${ }^{102}$ A variant of the territorial system that has been proposed is a system of formulary apportionment for taxing the corporate income of multinational firms. Under this proposal, the US tax base for multinational corporations would be calculated based on a fraction of their worldwide income, determined by the share of their worldwide sales that occur in the US. Only the portion of corporate profits commensurate with the apportionment formula would be consolidated. ${ }^{103}$

The move toward a territorial system has been advocated by Desai and Hines on the basis of a new standard denominated "capital ownership neutrality" ("CON".) They point out that the traditional CEN model assumes that (i) an outbound direct investment by a US firm is completely replaced by an inbound direct investment of a foreign firm and (ii) the US income tax liability incurred by that inbound investment is identical to the tax revenues that would have been obtained had the US multinational made the domestic investment. Desai and Hines propound that CON requires that "world welfare is maximized if the identities of capital owners are unaffected by tax rate differences." 104 In practice, they argue that decisions by US investors - specifically acquisitions of target assets in other countries - should not be distorted by the higher US taxes that affect those US investors. Consequently, CON suggests that the US should adopt a variation of the territorial tax system in which foreign income would be exempted, deductions incurred by the US parent company related to the production of that foreign income would be allowed, and foreign corporate losses would not be fully consolidated.

A proposal for national neutrality that, like the CON approach, looks to protect US competitiveness, would adjust the nature of the foreign tax credit by making US taxpayers indifferent between paying foreign taxes and US taxes. Taxes paid to the US increase US revenues and make a bigger contribution to the welfare of US taxpayers than taxes paid to foreign governments. So it has been argued that it is preferable for US taxpayers to pay US taxes rather than foreign taxes, and thus the standard of "national neutrality" which makes foreign taxes deductible (rather than creditable) should be

101 According to CIN a firm should face the same tax burden in operating in a foreign country as do its domestic competitors in that foreign country. CIN, therefore, implies taxation only in the source-country under a territorial system adopted the residence-country. CIN would promote worldwide welfare by ensuring that investments are made on the basis of after-tax income at country level and implies a convergence of after-tax returns; see Michael S. Knoll, Reconsidering International Tax Neutrality, 64 TAX L. REV. 99, 119$21(2011)$

${ }^{102}$ Clifton Fleming, Jr. et al., supra note 79, at 149-50; J. Clifton Fleming, Jr., Robert J. Peroni \& Stephen E. Shay, Some Perspectives From the United States on the Worldwide Taxation vs. Territorial Taxation Debate, 3 J. Austl. Tax Teachers Ass'N35, 44 (2008); Lawrence Lokken, Does the U.S. Tax System Disadvantage U.S. Multinationals in the World Marketplace?, 4 J. TAX'N GLOBAL TransaCtions 43 (2004).

${ }^{103}$ Reuven S. Avi-Yonah, Kimberly A. Clausing \& Michael C. Durst, Allocating Business Profits for Tax Purposes: A Proposal to Adopt a Formulary Profit Split, 9 Fla. TAX ReV. 497, 498 (2009); Reuven S. Avi-Yonah \& Ilan Benshalom, Formulary Apportionment-Myths and Prospects, 3 WorLD TAX J. 371, 380-81 (2011); see also Julie Roin, CAN the Income Tax Be Saved? The Promises and Pitfalls of ADOPTING WORLDWIDE FORMULARY APPORTIONMENT 61, 171-75, 182-85 (2008).

${ }^{104}$ Mihir A. Desai \& James R. Hines Jr., Evaluating International Tax Reform, 56 NAT'L TAX J. 488, 494-96 (2003); Mihir A. Desai \& James R. Hines, Jr., Old Rules and New Realities: Corporate Tax Policy in a Global Setting, see supra note 77, at 956-57. 
adopted. ${ }^{105}$ Under national neutrality, like under the proposed territorial system, foreign corporate profits and losses would not be consolidated.

Why then both the worldwide consolidation and the territorial approach, in spite of radical differences, would incentivize the US to become a party to a multilateral system of sharing of Global Corporate Tax Information? Worldwide tax consolidation would obviously require US parent companies to pool the relevant financial and tax data on profits and losses reported by the consolidated companies and compute consolidated profit and losses on the basis of common rules. This would be accomplished by unilaterally imposing reporting requirements on foreign affiliate companies, but of course there would also be an interest for the US to rely on a multilateral system of Global Corporate Tax Information established at the international level. The territorial system would not require systemic consolidation of tax data, but may include minimum taxes on foreign active income, ${ }^{106}$ with the practical consequence that it also would require reporting of foreign corporate profits to US tax authorities, so that also in a territorial option the US would have an interest to rely on a multilateral system of Global Corporate Tax Information.

The game theory perspective adopted here shows that the CCCTB is essentially a multilateral treaty that relies on qualified corporate intermediaries - the consolidating and consolidated companies - to achieve the full sharing of Global Corporate Tax Information by the participating countries. Thus the US might request EU assistance in amassing Global Corporate Tax Information. In exchange the US would provide similar information relating to US operations of EU-based firms to EU tax authorities or to the authorities of individual Member States. This reciprocity could be accomplished through a treaty between the EU and the US which would be connected with the CCCTB framework. In the CCCTB system, each EU-participant allows other EU participants full access to relevant information about domestic corporate profits and losses, and, in exchange, is allowed to tax a portion of consolidated profits on the basis of the apportionment formula. In a potential treaty for the sharing of Global Corporate Tax Information between the US and the EU, however, there would be no need to apply the apportionment formula because the quid pro quo would be simply the exchange of Global Corporate Tax Information between the US and the EU.

In conclusion, there are at least four good reasons why the US should subject itself to such a multilateral treaty on the exchange of Global Corporate Tax Information. First, such a treaty would not limit in any manner the scope of US territorial and extraterritorial tax jurisdiction as it would only concern the sharing of information. Second, the multilateral regulation of exchange of Global Corporate Tax Information would not pose the daunting problems faced by FATCA as it would essentially rely on the sharing by the US and other treaty partners of accessible accounting and tax data normally managed by corporations in OECD countries. Third, multilateral regulation of exchange of Global Corporate Tax Information would provide assurance to the US that other countries would cooperate, without the need to resort to the treaty-based exchange of

${ }^{105}$ See: Daniel Shaviro, Why Worldwide Welfare as a Normative Standard in U.S. Tax Policy?, 60 TAX L. Rev. 155, 178 (2007); Daniel Shaviro, The Case Against Foreign Tax Credits, 3 J. LEGAL ANALYSIS 65, 74-77 Daniel Shaviro, The Rising Tax-Electivity of U.S. Corporate Residence, The David R. Tillinghast Lecture, NYU School of Law (Sept. 21, 2010), in 64 TAX L. REV. 377, 393, 393 n. 43; Kimberly A. Clausing \& Daniel Shaviro, A Burden-Neutral Shift from Foreign Tax Creditability to Deductibility?, 64 TAX L. REV. 431 (2011).

106 See, e.g., Harry Grubert \& Rosanne Altshuler, supra note 101, at 8-13, 35-40. 
information contemplated by Article 26 of the OECD Model Convention. Finally, as the interactions would be repeated over time the US could count on the expected behavior of EU countries based on the incentives of reciprocity. 